\title{
A study of thermal comfort in residential buildings on the Tibetan Plateau, China
}

Article

Accepted Version

Creative Commons: Attribution-Noncommercial-No Derivative Works 4.0

Yu, W., Li, B., Yao, R., Wang, D. and Li, K. (2017) A study of thermal comfort in residential buildings on the Tibetan Plateau, China. Building and Environment, 119. pp. 71-86. ISSN 03601323 doi: https://doi.org/10.1016/j.buildenv.2017.04.009 Available at https://centaur.reading.ac.uk/70095/

It is advisable to refer to the publisher's version if you intend to cite from the work. See Guidance on citing.

To link to this article DOI: http://dx.doi.org/10.1016/j.buildenv.2017.04.009

Publisher: Elsevier

All outputs in CentAUR are protected by Intellectual Property Rights law, including copyright law. Copyright and IPR is retained by the creators or other copyright holders. Terms and conditions for use of this material are defined in the End User Agreement.

\section{www.reading.ac.uk/centaur}

\section{CentAUR}

Central Archive at the University of Reading

Reading's research outputs online 


\title{
Building and Environment
}

Available online 15 April 2017

In Press, Accepted Manuscript — Note to users

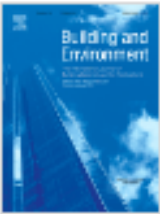

\section{A study of thermal comfort in residential buildings on the Tibetan Plateau, China}

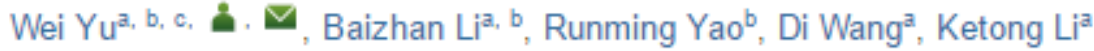 \\ \pm Show more
}

http://doi.org/10.1016/j. buildenv.2017.04.009

Get rights and content

\begin{abstract}
a Joint International Research Laboratory of Green Buildings and Built Environments, Ministry of Education, Chongqing University, 400045, China.

${ }^{\mathrm{b}}$ National Centre for International Research of Low-Carbon and Green Buildings, Ministry of Science and Technology, Chongqing University, 400045, Chongqing, China.

${ }^{\mathrm{c}}$ Key Laboratory of Eco-environments in the Three Gorges Reservoir Region, Ministry of Education, Chongqing University, 400045, Chongqing, China.
\end{abstract}

\begin{abstract}
Tibet is located on the Qinghai-Tibetan Plateau in China, the highest and largest plateau in the world. It is in the Cold and Severe Cold zones according to the Chinese climatic division for building design and has unique climatic characteristics and traditional cultural background. In order to obtain a comprehensive understanding about the real indoor thermal environment and the residents' thermal comfort status in Tibet, a field investigation of residential buildings was conducted in the Tibetan Alpine region with on-site environmental parameter measurements and a simultaneous survey using a subjective thermal comfort questionnaire. Based on the analysis of the data collected from the field study, the value of the adaptive coefficient $\lambda$ in the adaptive thermal comfort model $a P M V=\frac{P M V}{1+\lambda P M V} \quad$ suitable to the Tibet area has been obtained as -0.34 ; and thus the acceptable thermal comfort temperature range for residential buildings in this area has been produced. The research findings provide comprehensive knowledge and a useful reference for the development of a design and evaluation standard for indoor thermal environments in the Tibet region.
\end{abstract}

Key Words: Tibetan Plateau; indoor thermal environment; thermal comfort; residential buildings; field investigation. 


\section{Introduction}

Tibet, located in the Qinghai-Tibetan Plateau China, the highest and largest plateau in the world, has distinct climatic characteristics [1] and unique traditional living styles [2]. The main climatic characteristics of Tibet can be summarized as hypobaric hypoxia, low average temperature and relative humidity, high wind velocity and solar radiation, and low rainfall. Many internal thermal environment investigations of traditional dwellings have been conducted in this area [3-14] and some other adjacent areas, including western China [15, 16], India [17] and Nepal [18-20]. This research has shown that the residents had formulated their own lifestyle and measures adapted to the severe thermal environment.

Research on thermal comfort conditions and human adaptation in high altitude areas has attracted many scholars due to their unique climatic conditions. Some [21] studied the physiological adaptation of the original inhabitants of an area. Some others [22-28] focused on the building technologies or designs that improve thermal comfort whilst others dealt with the effect of the special thermal environment on occupants' thermal comfort in these areas. The majority of Tibet lies within the 'cold' and the 'severe cold' zones of China [29], which, according to several studies in these climate zones, have a lower comfort temperature range than those in warmer zones, [10, 30-32]. The comfort temperature varied because of thermal adaption [33-35], and also related to buildings styles [4, 36, 37] and seasons [38]. Besides that, the significant impacts of hypobaric hypoxia on physiological and subjective responses to the thermal environment were also recognized [39].

In order to study the effects of hypobaric conditions on people's thermal responses, Ohno $\mathrm{H}$ et al. [40] conducted experiments to clarify the interactive effects between barometric and thermal events on people's thermal comfort under hypobaric conditions (pressures about 30\% below that at sea level) and the results showed that some physiological features change when the altitude increases which leads to subjects finding it difficult to express their thermal state. Cui et al. [41] studied the effect of low pressure on human physiological responses in an artificial chamber, and found significant effects when it decreased to $85 / 70 \mathrm{kPa}$. Wang, H. et al. [42] conducted an experiment in a decompression chamber to simulate the hypobaric conditions, and found that people become more sensitive to draught and expect lower air movements. It was concluded that the hypobaric environment tends to make people feel cooler. Studies on the thermal environment in high altitude areas are limited, Liu, Y. et al. [34] carried out a field study of the thermal comfort conditions in residential buildings in high-altitude regions with sub-atmospheric pressure in China. They found that the neutral temperature in winter is much higher than the mean indoor air temperature. Wang, D. et al. [43] investigated the indoor thermal environment of residential buildings in Lhasa in winter and found that the low indoor humidity has a negative impact on thermal comfort. As to the strategies to improve the thermal environment, Chang and Santee [44] studied the clothing insulation in a hypobaric environment and revealed that evaporation was the dominant process at the skin surface, while convection dominated at the outer clothing surface. This resulted in the skin temperature being found to be lower than it is at sea level, but the clothing temperature was found to be higher than it is at sea level. In order to study the strategic planning of the architecture design, Luo [45] carried out a field study on the existing buildings at an altitude of 5,347m on a mountain in Tibet and found that the solar house is an effective way to improve the thermal environment.

However, very little previous research has studied the adaptive thermal comfort model for indoor 
thermal environments in this area. The theories of adaptive thermal comfort are widely used to evaluate indoor thermal environments in 'real world' buildings [46-48] due to human thermal adaptation, and are incorporated in most current thermal comfort standards worldwide [49-51]. It is known that indoor thermal environments and the characteristics of human thermal comfort differ between different areas [52] due to cultural, climatic, and social differences and personal experience and preferences [53, 54]. Yao et al. [55] proposed a theoretical adaptive model of thermal comfort (aPMV), which has proved to be useful in similar geodetic latitude regions in India [56] and China [57]. However, due to its high altitude on the Qinghai-Tibetan Plateau, the region's unique climatic characteristics have distinct impacts on indoor thermal environments compared to the other regions in the same climatic zone. Therefore, the open questions remaining are: what is the real situation of the indoor thermal environment and how do the local residents respond to it in order to achieve 'thermal comfort'?

In summary, there are many studies for Tibet residential buildings focused on different aspects, but little comprehensive study on indoor adaptive thermal comfort based on the theoretical adaptive models. Unique characteristics do exist in terms of local climate and its impact on the indoor thermal environment and building design. Therefore, the existing thermal comfort and indoor environment design standards may not be suitable to this area. In order to fill the gap, the aim of this research is to gain a comprehensive understanding of the indoor thermal environment and the occupants' thermal comfort in order to develop a thermal comfort model suitable to this area. Such research findings will provide information and knowledge for indoor environmental design, operation, and evaluation in this specific region.

\section{Background information}

\subsection{Climatic characteristics}

Due to the high altitude, Tibet has higher annual solar radiation and lower annual average air temperature compared to the other cities in the same climate zone. Table 1 shows meteorological parameters for the outdoor climate of the typical cities in the Tibetan Plateau area（Lhasa and Sining). Table 1: A comparison of the meteorological parameters of typical cities on the Tibetan Plateau [58].

\begin{tabular}{|c|c|c|c|c|c|c|c|}
\hline \multirow[b]{2}{*}{ City } & \multicolumn{2}{|c|}{ Observatory site } & \multirow{2}{*}{$\begin{array}{l}\text { Annual } \\
\text { average air } \\
\text { temperature } \\
\left({ }^{\circ} \mathrm{C}\right)\end{array}$} & \multirow{2}{*}{$\begin{array}{l}\text { Average } \\
\text { temperature of } \\
\text { the hottest month } \\
\left({ }^{\circ} \mathrm{C}\right)\end{array}$} & \multirow{2}{*}{$\begin{array}{l}\text { Annual total } \\
\text { solar radiation } \\
\left(\mathrm{MJ} / \mathrm{m}^{2}\right)\end{array}$} & \multirow{2}{*}{$\begin{array}{l}\text { Altitude } \\
\text { (m) }\end{array}$} & \multirow{2}{*}{$\begin{array}{r}\text { Pressure } \\
(\mathrm{KPa})\end{array}$} \\
\hline & $\begin{array}{l}\text { North } \\
\text { latitude }\end{array}$ & $\begin{array}{l}\text { East } \\
\text { longitude }\end{array}$ & & & & & \\
\hline Lhasa & 29.67 & 91.13 & 8.30 & 16.40 & 7331.20 & 3648.9 & 65.24 \\
\hline Sining & 36.72 & 101.75 & 5.93 & 17.69 & 5601.00 & 2295.2 & 77.41 \\
\hline Changdu & 31.15 & 97.17 & 7.45 & 15.40 & 6078.63 & 3306.0 & 68.16 \\
\hline Nyingchi & 29.67 & 94.33 & 9.00 & 15.82 & 6359.40 & 2991.8 & 70.73 \\
\hline
\end{tabular}

The average annual dry-bulb temperature in these typical cities is less than $10^{\circ} \mathrm{C}$, even in the hottest month the highest average temperature is below $17.69^{\circ} \mathrm{C}$. Meanwhile, the annual total solar radiation is more than $5,000 \mathrm{MJ} / \mathrm{m}^{2}$, which represents a very rich solar resource.

\subsection{Residential building types}

The research team carried out a large number of surveys by visiting local residential buildings in Tibet. Three typical types of residential buildings are identified; namely, traditional buildings, new buildings and solar houses (see Fig.1). Residential buildings are usually one- to three-story, low-rise buildings. External walls are usually composed of stone or rammed-earth, load-bearing walls coated with plaster 
on one or both sides. The internal supporting beams and columns are composed of timber. Due to the abundant solar energy, the south-facing wall is usually glazed to provide passive solar heating in winter. Based on such a construction type, the thermal properties of external walls for the three typical residential building types are listed in Table 2. From this table we can see that the traditional residential building has the highest thickness.
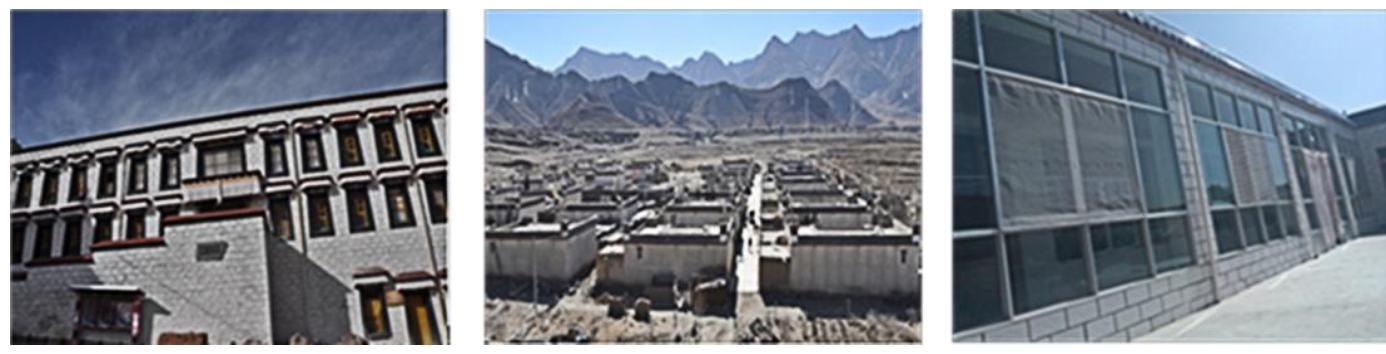

(a) Three-story stone-wall (b) One-story rammed-earth wall (c) One-story solar house

Fig. 1: Typical Tibetan residential buildings

Table 2: Thermal properties of external walls of typical residential buildings in Tibet

\begin{tabular}{|c|c|c|c|c|c|c|c|}
\hline Building Type & Index & $\begin{array}{l}\text { Thermal } \\
\text { Conductivity } \\
(\mathrm{W} / \mathrm{m} \cdot \mathrm{k})\end{array}$ & $\begin{array}{l}\text { Thermal } \\
\text { Capacity } \\
\left(\mathrm{W} / \mathrm{m}^{2} \cdot \mathrm{k}\right)\end{array}$ & $\begin{array}{l}\text { Thickness } \\
\text { (m) }\end{array}$ & $\begin{array}{l}\text { Thermal } \\
\text { Resistance } \\
\left(\mathrm{m}^{2} \cdot \mathrm{k} / \mathrm{w}\right)\end{array}$ & $\begin{array}{c}\text { Thermal } \\
\text { Transmittance } \\
\left(\mathrm{w} / \mathrm{m}^{2} . \mathrm{k}\right)\end{array}$ & $\begin{array}{c}\text { Thermal } \\
\text { Inertia } \\
\text { Index (D) }\end{array}$ \\
\hline \multirow{5}{*}{$\begin{array}{l}\text { Traditional } \\
\text { Tibetan } \\
\text { Dwelling }\end{array}$} & Lime & & & & \multirow{5}{*}{0.839} & \multirow{5}{*}{1.192} & \multirow{5}{*}{6.450} \\
\hline & Gypsum & 0.70 & 7.56 & 0.02 & & & \\
\hline & plaster & & & & & & \\
\hline & Stone wall & 1.28 & 12.54 & 0.6 & & & \\
\hline & $\begin{array}{l}\text { Gypsum } \\
\text { plaster }\end{array}$ & 0.23 & 4.11 & 0.02 & & & \\
\hline \multirow[b]{2}{*}{$\begin{array}{l}\text { New Tibetan } \\
\text { Dwelling }\end{array}$} & $\begin{array}{l}\text { Rubble } \\
\text { masonry }\end{array}$ & 1.28 & 12.54 & 0.24 & \multirow[b]{2}{*}{0.478} & \multirow[b]{2}{*}{2.091} & \multirow[b]{2}{*}{2.705} \\
\hline & $\begin{array}{l}\text { Calcium } \\
\text { sulphate } \\
\text { plaster }\end{array}$ & 0.23 & 4.11 & 0.02 & & & \\
\hline South-facing & \multirow[b]{2}{*}{ Glass } & \multirow[b]{2}{*}{0.88} & \multirow[b]{2}{*}{12.56} & \multirow[b]{2}{*}{0.02} & \multirow[b]{2}{*}{0.186} & \multirow[b]{2}{*}{5.367} & \multirow[b]{2}{*}{0.284} \\
\hline $\begin{array}{c}\text { Direct-gain } \\
\text { Passive Solar } \\
\text { House }\end{array}$ & & & & & & & \\
\hline
\end{tabular}

\section{Research Methodology}

In this research, primary data on the subjective evaluation of indoor thermal comfort and outdoor environmental parameter data were collected through onsite measurements and subjective questionnaire surveys. The monitored environmental parameters and the surveyed data have been subjected to statistical analysis. The existing adaptive thermal comfort model - aPMV - has been applied to study the characteristics of indoor thermal environments in residential buildings in Tibet.

\subsection{Onsite subjective survey}

A questionnaire survey on occupants' thermal sensation and onsite physical environmental parameter measurements was conducted in 527 residential buildings. The questionnaire survey aimed to obtain residents' thermal sensation and included questions on the basic information about the buildings, residents' demographic information such as gender, age, regional location, occupancy time, and living 
habits, and the present measures regarding the regulation of the indoor thermal environment. Respondents' subjective thermal sensation vote (TSV) was evaluated using the 7-point scale suggested by ASHRAE Standard 55 [51]. The thermal sensation scales are listed in Table 3.

Table 3: The scale of thermal, humidity and draft sensation

\begin{tabular}{ccccccccc}
\hline & Temperature & Hot & Warm & $\begin{array}{c}\text { Slightly } \\
\text { warm }\end{array}$ & Neutral & $\begin{array}{c}\text { Slightly } \\
\text { cool }\end{array}$ & Cool & Cold \\
\cline { 2 - 9 } Sensation & Humidity & $\begin{array}{c}\text { Very } \\
\text { humid }\end{array}$ & Humid & $\begin{array}{c}\text { Slightly } \\
\text { humid }\end{array}$ & Neutral & Slightly dry & Dry & $\begin{array}{c}\text { Very } \\
\text { dry }\end{array}$ \\
\cline { 2 - 9 } & $\begin{array}{c}\text { Draft } \\
\text { Sensation }\end{array}$ & $\begin{array}{c}\text { Very } \\
\text { stuffy }\end{array}$ & Stuffy & $\begin{array}{c}\text { Slightly } \\
\text { stuffy }\end{array}$ & Neutral & $\begin{array}{c}\text { Slightly } \\
\text { breezy }\end{array}$ & Breezy & $\begin{array}{c}\text { Very } \\
\text { breezy }\end{array}$ \\
\hline $\begin{array}{c}\text { Scale } \\
\text { points }\end{array}$ & & +3 & +2 & +1 & 0 & -1 & -2 & -3 \\
\hline
\end{tabular}

Onsite surveys were conducted from $5^{\text {th }}$ July to $25^{\text {th }}$ August in 2013 , from January $13^{\text {th }}$ to $22^{\text {nd }}$ February 2014, and $10^{\text {th }}$ July to $29^{\text {th }}$ August 2014. The surveys and measurements were conducted during the daytime between 8:30 and 19:30. The thermal sensation and environmental parameters were recorded at one-hour intervals. A total of 1,741 copies of a questionnaire were distributed through field studies in 7 districts in the Tibet region, including the three cities of Lhasa, Shigatse and Lhoka, during the two seasons of summer and winter. A total of 1,258 completed questionnaires were received, of which 1,182 were valid. Among the 1,182 completed valid questionnaires, 609 were from the summer survey and 573 were from the winter one. The distribution of the valid questionnaires over the main regions is: 351 from Lhasa, 196 from Shigatse, and 103 from Lhoka. Fig. 2 shows the geographic location of the surveyed areas.
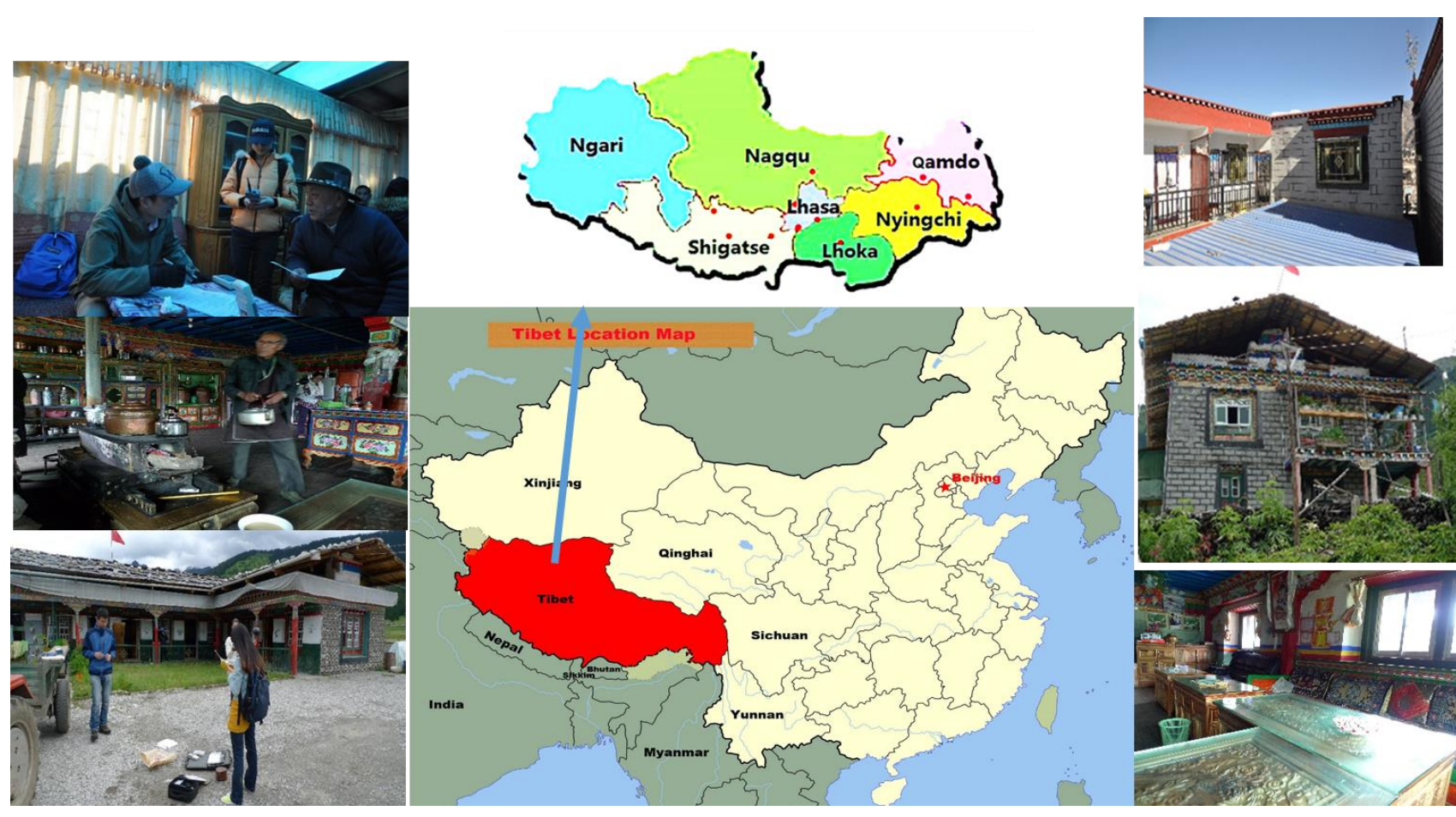

Note: Spots represent the towns investigated

Fig. 2: The investigated Tibetan cities and the survey scene 
Of the 1,182 respondents, 579 were male and 603 were female. The subjects' ages range between 68 years (the oldest) and 16 years (the youngest). The respondents' basic information is presented in Table 4.

Table 4: Respondents' basic information

\begin{tabular}{|c|c|c|}
\hline Total sample & $1,182 \quad(6$ & mer, 573 in winter) \\
\hline \multirow{2}{*}{ Gender } & Male & $579(49 \%)$ \\
\hline & Female & $603(51 \%)$ \\
\hline \multirow{6}{*}{ Age [Years] } & Maximum & 68 \\
\hline & Minimum & 16 \\
\hline & Average & 33 \\
\hline & $16-30$ & 42.70[Average, $\%$ ?] \\
\hline & $30-50$ & 43.07[Average, \%?] \\
\hline & $50-70$ & 15.73[Average, \%?] \\
\hline
\end{tabular}

\subsection{Onsite parameter measurement}

The measured environmental parameters include indoor and outdoor air temperature, humidity, globe temperature, and air velocity. The following instruments have been used to measure the physical environmental parameters: a Dwyer 485-2 digital temperature and humidity meter, a Testo 425 Hotwire Anemometer, and a SWEMA Black Ball temperature instrument. The measuring range for each instrument is given below:

- Dwyer 485-2 digital temperature and humidity meter:

Temperature range: $-30 \sim+85^{\circ} \mathrm{C}$; Accuracy: $\pm 0.5^{\circ} \mathrm{C}$;

Humidity range: $0 \sim 100 \%$, Accuracy: $\pm 2 \%$

- RH Testo 425 Hot-wire Anemometer:

Velocity Range: 0-20m/s, System Accuracy: $\pm 0.03 \mathrm{~m} / \mathrm{s}$

- SWEMA Black Ball temperature instrument:

Temperature Range: $-20 \sim+50^{\circ} \mathrm{C}$, Accuracy: $\pm 0.3^{\circ} \mathrm{C}$.

Due to the constraints and complications of measuring radiant temperature, the globe temperature was measured instead in this study. Many other researchers popularly use the globe temperature to estimate radiant temperature, particularly in studies of residential buildings [59].

The onsite measurement is based on the method recommended in ASHRAE 55-2013 [51]. More specifically, for the indoor environment parameters, the center of the room and the people's occupancy areas were selected as the representative points for measurement. The measurements of temperature, humidity, and air speed were conducted on the height of $1.1 \mathrm{~m}$ because the occupants were usually in a sitting position at home. For a few subjects in standing postures, the measurement point was set at $1.6 \mathrm{~m}$ above the floor. As to the outdoor environment parameters, the measurements were conducted on the open ground near to the tested house. The instruments were settled out of direct sunlight at a height of $1.1 \mathrm{~m}$. The recorded air velocity was the average over a 2-minute period.

\subsection{Operative temperature and neutral temperature}

The indoor operative temperature $\left(t_{\mathrm{op}}\right)$ can be calculated as the average value of the indoor air temperature $\left(t_{\mathrm{a}}\right)$ and indoor mean radiant temperature $\left(t_{r}\right)$ when metabolic rates are between 1.0met and $1.3 \mathrm{met}$, not in direct sunlight, and not exposed to air velocities greater than $0.20 \mathrm{~m} / \mathrm{s}$. The indoor thermal environments of the surveyed homes fall into this category. 
The indoor operative temperature can be calculated using the following formula:

$$
t_{\mathrm{op}}=\left(t_{\mathrm{a}}+t_{\mathrm{r}}\right) / 2
$$

The parameter air temperature $t_{\mathrm{a}}$ was directly measured and the mean radiant temperature $t_{\mathrm{r}}$ was assumed to be approximately equal to the globe temperature $t_{\mathrm{g}}$ [59] which can be measured directly. The neutral temperature can be regarded as the temperature at which the occupant's thermal sensation vote is 'neutral'.

\subsection{The aPMV model}

Yao et al. [55] established a theoretical adaptive model based on the thermal comfort-adaptive Predicted Mean Vote (aPMV) using the "black box" theory. It reveals the relationship of the lab-based, steady-state Predicted Mean Vote (PMV) [60] and the actual mean vote in the real environment taking into account occupants' psychological and behavioral adaptations and so on.

The aPMV model is presented as follows:

$$
\mathrm{aPMV}=\frac{P M V}{1+\lambda \times \mathrm{PMV}}
$$

" $\lambda$ " is the adaptive coefficient.

The aPMV model has been adapted in the Chinese national standard "Evaluation standard for the indoor thermal environment in civil buildings" GB/T50785-2012 [50].

The aPMV model can be used to predict the actual thermal sensation in dynamic environmental conditions. The determination of the value of " $\lambda$ " is based on field studies considering the local climate, culture, and social background.

\subsection{The statistical methods}

After the raw data was collected from the field study, several data processing methods were used for analyzing the results [61]. Using different questionnaires in the same room produces the bin method in section 4.1, whilst being plotted as every questionnaire in other sections. Occupants' clothing insulation was calculated using the clo-checklist method, according to ISO7730: Annex C:

'Estimation of thermal insulation of clothing ensembles' [62]. The indoor operative temperature bins are created for every $1^{\circ} \mathrm{C}$, and used to build linear regressions with the value from thermal comfort models. Coefficient $\mathbf{R}^{2}$ values were determined and used to assess the power of the regression models. A confidence level of $95 \%$ was adopted in the statistical analysis in this paper.

\section{Results and Analysis}

\subsection{Comparison between globe temperature and air temperature}




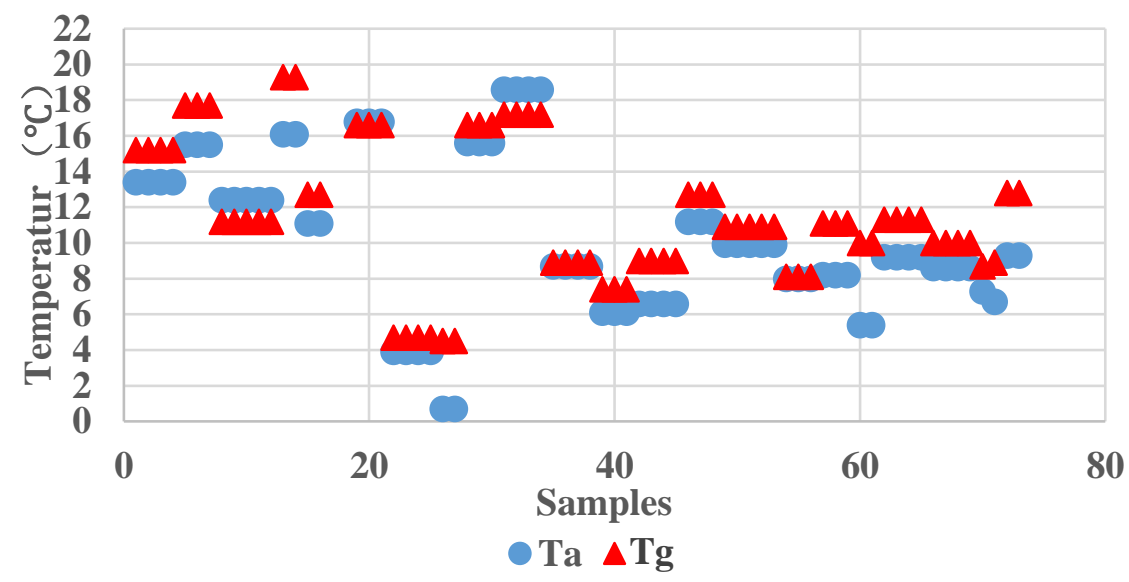

Fig. 3: A comparison between globe (Tg) and air temperatures (Ta)

Based on the data obtained, we compared the indoor globe temperature and indoor air temperature as simultaneously measured (see Fig. 3). The proportion of samples for which the globe temperature is higher than the air temperature is up to $83.10 \%$. The average value of the difference between the globe temperature and air temperature is $1.3^{\circ} \mathrm{C}$. It is thus clear that the globe temperature is higher than the air temperature due to the high solar radiation intensity. Therefore, the operative or globe temperature is used instead of the indoor air temperature in this study.

\subsection{Annual indoor environmental parameters}

According to the measured data, the outdoor air temperature in Tibet ranges between -20 to $32.5^{\circ} \mathrm{C}$, and the indoor air temperature between $0.5^{\circ} \mathrm{C}$ to $30^{\circ} \mathrm{C}$. Fig. 4 shows the relationship of the indoor and outdoor air temperatures. In order to compare the relationship of the indoor and outdoor temperatures, a reference line of $t_{\text {out }}=t_{\text {in }}$ is drawn in Fig. 4. For the purpose of explanation, we categorize three zones according to the outdoor air temperature. These are Zone A (lower than $0^{\circ} \mathrm{C}$ ), Zone $\mathrm{B}$ (between 0 and $20^{\circ} \mathrm{C}$ ) and Zone $\mathrm{C}$ (greater than $20^{\circ} \mathrm{C}$ ). In Zone A, indoor air temperatures fluctuate greatly within a range of $0^{\circ} \mathrm{C}-26^{\circ} \mathrm{C}$. This is due to the diversities in the use of heaters. In Zone B, the indoor air temperatures are almost always greater than the outdoor air temperatures. This is because the internal heat gains, including the heat gains from solar radiation and residents' activities, keep the indoor temperature higher than that outdoors. Furthermore, in this temperature range, the windows were almost always kept closed for warmth. In Zone $\mathrm{C}$, the indoor temperatures are almost always lower than those outdoors. This is because the building envelope plays the role of thermal insulation to prevent the fenestration of outdoor heat into the room. 


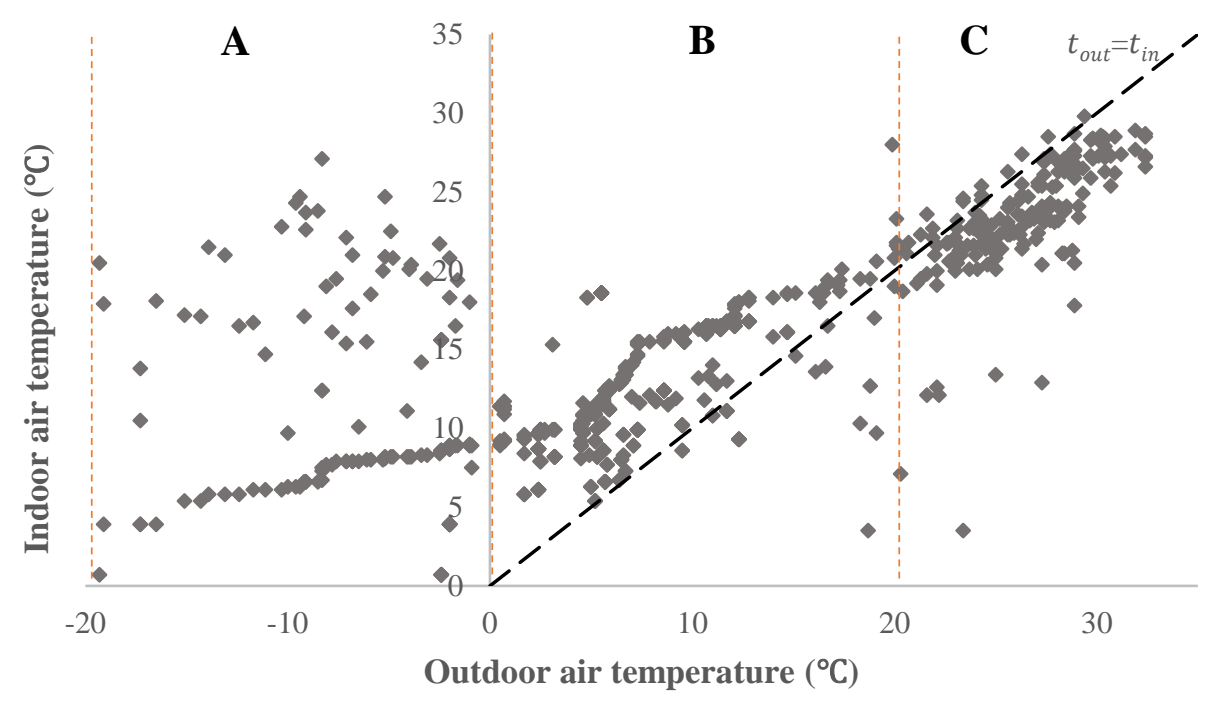

Fig. 4: Relationship between indoor and outdoor temperatures in Tibet

According to the survey, the indoor air temperature range is between $13.5^{\circ} \mathrm{C}$ and $30.0^{\circ} \mathrm{C}$ in the summer (June, July and August) and between $0.5^{\circ} \mathrm{C}$ and $24.0^{\circ} \mathrm{C}$ in winter (November, December, January and February). Fig. 5 shows the indoor air temperature frequency distribution. From the figure we can see that the frequency of the temperatures between $21^{\circ} \mathrm{C}$ and $24^{\circ} \mathrm{C}$ is about $25 \%$, and the temperatures under $18^{\circ} \mathrm{C}$ account for about 37\% all year round. Fig. 6 shows the frequency distribution of the indoor air relative humidity. From the figure we can see that that the periods when relative humidity is lower than $40 \%$ account for nearly $55 \%$ all year round.

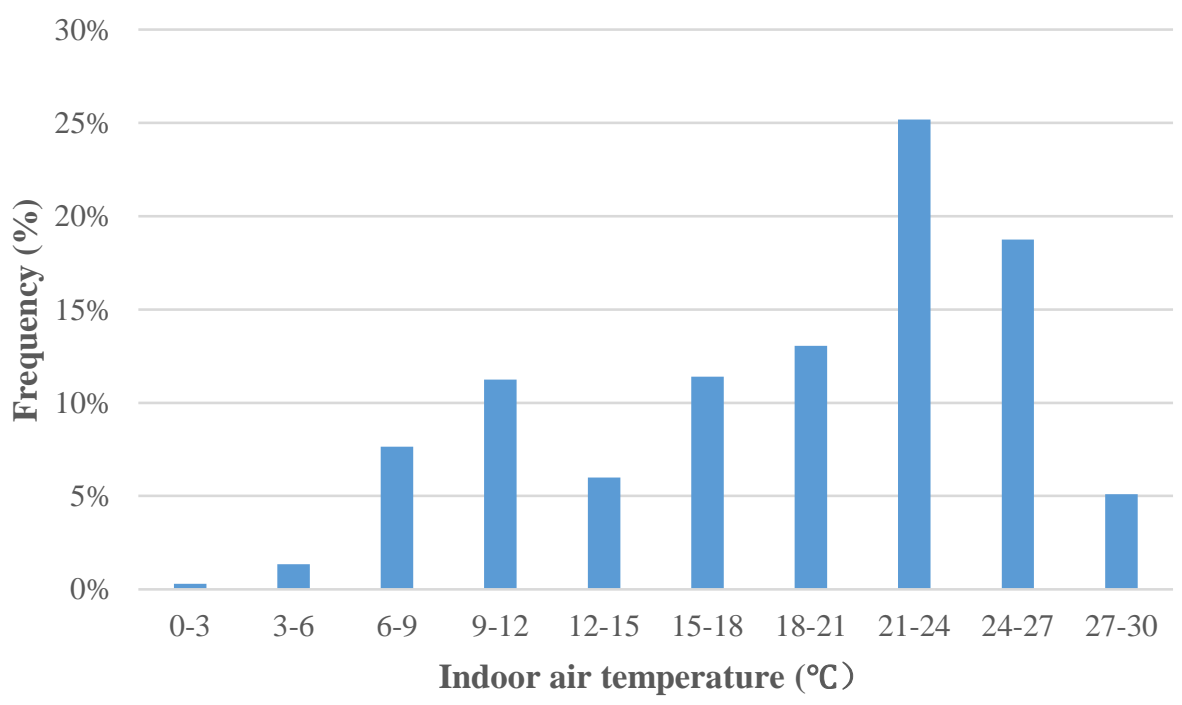

Fig. 5: Frequency of the indoor air temperature all year round 


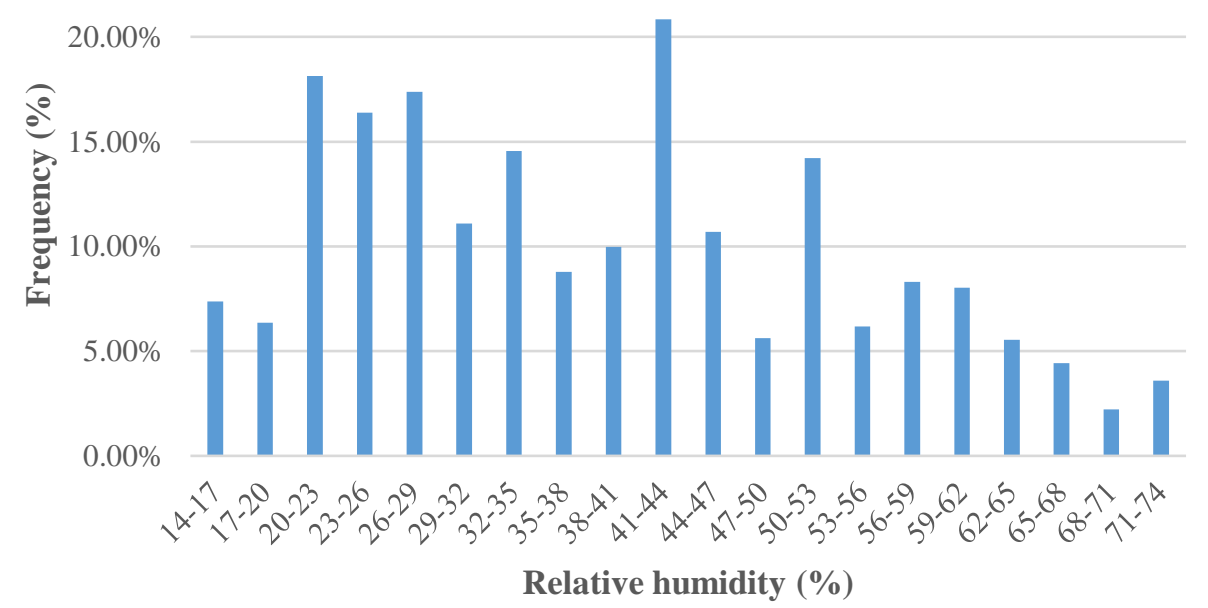

Fig. 6: Frequency of the indoor air relative humidity all year round

\subsection{Adaptive behavior of residents}

Tibet residents have a unique traditional lifestyle and adaptive measures to secure their thermal comfort. In summer, residents use natural ventilation to improve warm/hot indoor conditions; while in winter, they usually wear more clothes, drink butter and sweet tea, or use a stove/fire heater to keep warm as their homes lack central heating systems. Butter tea is a kind of high-calorie hot drink which not only replenishes their daily energy requirements, but also enables people to keep warm in winter. Therefore, drinking a cup of warm butter tea or sweet tea has become a feature of the residents' lifestyle and an integral part of daily life for the families in Tibet, as shown in Fig. 7.

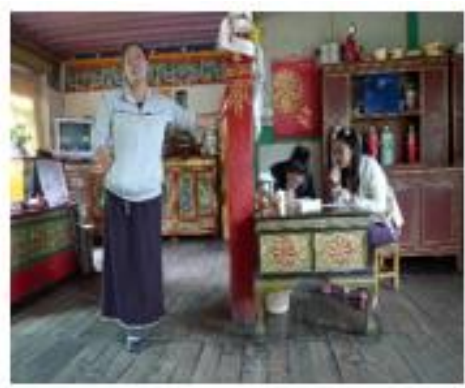

Tibetan dress in summer.

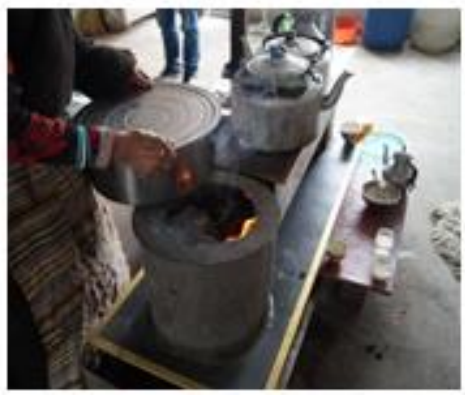

Indoor stove heating.

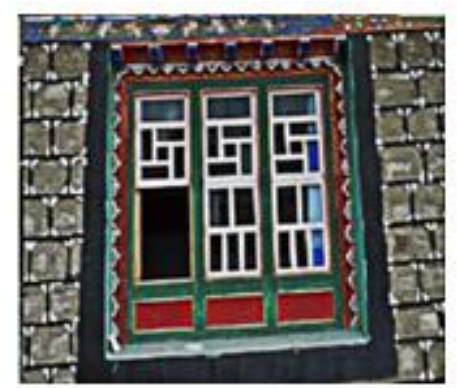

Small areas of windows and doors.

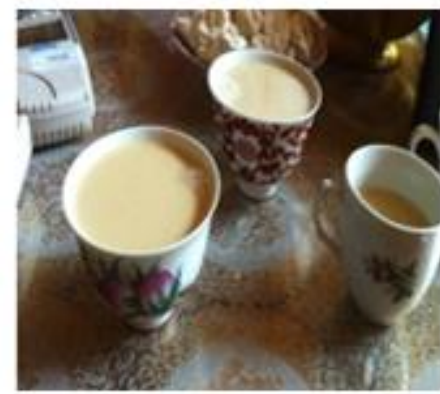

Drinking sweet tea or butter tea.

Fig. 7: Adaptive measures in summer and winter 


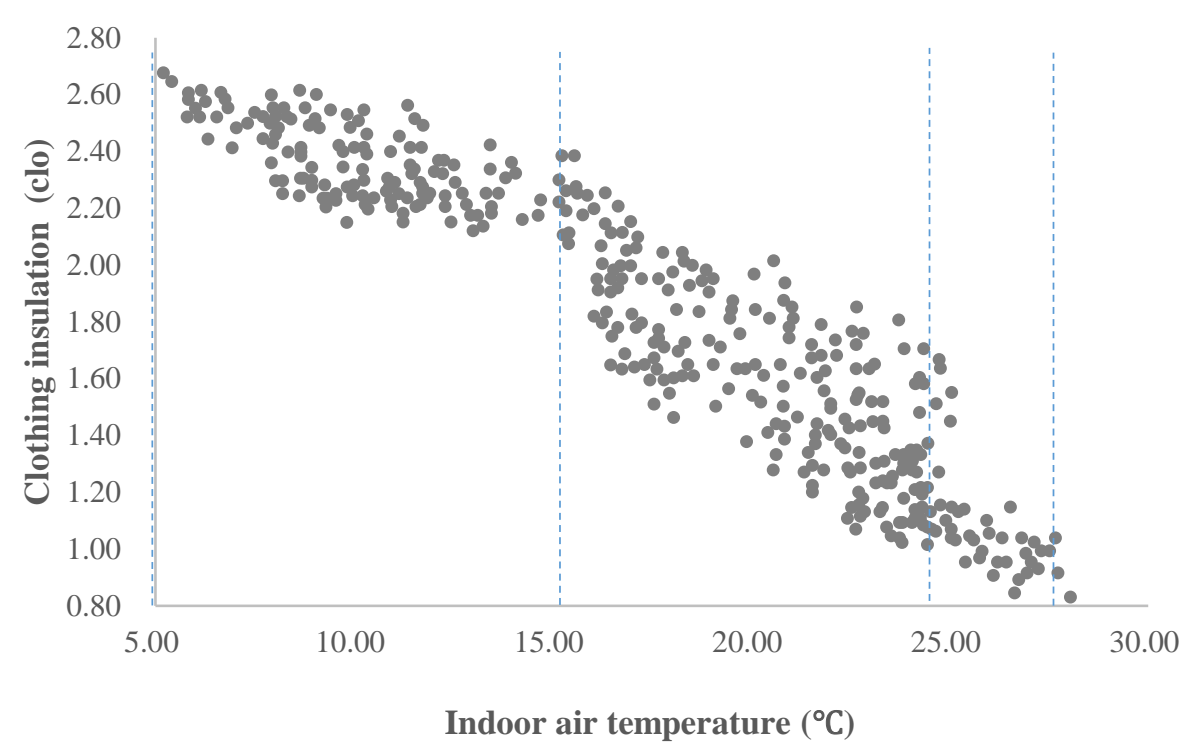

Fig. 8: Correlation between residents' annual clothing insulation with indoor air temperature

Fig. 8 shows a linear correlation between the residents' clothing insulation and indoor temperature. It can be seen that the clothing insulation levels decrease when the indoor temperatures increase. This phenomenon reflects the residents' lifestyle of changing clothing levels to keep themselves thermally comfortable. When the indoor temperature is lower than $16^{\circ} \mathrm{C}$, the clothing insulation changes slightly according with the indoor air temperature. When the indoor air temperature ranges between $16^{\circ} \mathrm{C}-25^{\circ} \mathrm{C}$ the fluctuation of clothing levels is more significant within the range between 2.3 clo to 1.0clo and the gradient is much steeper. When the indoor temperature is higher than $25^{\circ} \mathrm{C}$, the clothing insulation changes slightly with a gentle slope, which is mainly within the range between 1.1clo and 0.8 clo. Tibetan residents have a variety of traditional dress ranges all year round, such as the 'Chuba', the Tibetan-style robe, which is characterized by long sleeves, a loose waist, and large lapels.

\subsection{Indoor thermal environment}

The thermal sensation votes (TSV), humid sensation votes (HSV), and draft sensation votes (DSV) are shown in Fig. 9. From Fig. 9 (a) it can be seen that most residents felt comfortable in summer. 91.35\% of the votes for 'slightly warm', 'comfortable' and 'slightly cool' fall within the range -1 to +1 and, among those, the vote for 'comfortable' accounts for $57.57 \%(\mathrm{TSV}=0)$. The proportion of people having an acceptable humid sensation accounts for $87.88 \%$ (HSV -1 to +1), from which $59.68 \%$ (HSV $=0$ ) vote for 'comfortable'. The proportion of people having an acceptable draft sensation accounts for $91.58 \%(-1$ to +1$)$, among which the vote for 'comfortable' accounts for $62.3 \%(\mathrm{DSV}=0)$ in summer.

From Fig. 9 (b) it can be seen that the proportion of the votes from 'slightly warm', 'comfortable' and 'slightly cool' within the range of -1 to +1 accounts for $74.37 \%$ and among them the vote for 'comfortable' and 'slightly cool' accounts for 35.29\% (TSV $=0)$ and 30.25\% (TSV $=+1)$ respectively. The proportion of people having an acceptable humid sensation accounts for $53.44 \%(-1 \leq \mathrm{HSV} \leq+1)$, among which the votes for 'comfortable' and 'slightly dry' account for $12.15 \%$ (HSV = 0) and 39.27\% (HSV $=-1$ ) respectively. The proportion of people having an acceptable draft sensation accounts for $87.65 \%(-1$ to +1$)$, among which the proportion of people feeling comfortable accounts for $53.39 \%$ $(\mathrm{FSV}=0)$. Based on the analysis above, the indoor thermal sensation vote (TSV) is more dispersed compared to the other two thermal comfort sensations (HSV and DSV). This is because residents actively adjust the thermal environment by moving around for sunbathing, drinking hot drinks, moving 
closer to the stove, adding layers of clothing, and turning on electric heaters and other heating appliances. When HSV $=0$, the acceptable draught was the highest and the acceptable humid environment was the lowest with only $12.15 \%$ of residents feeling comfortable.

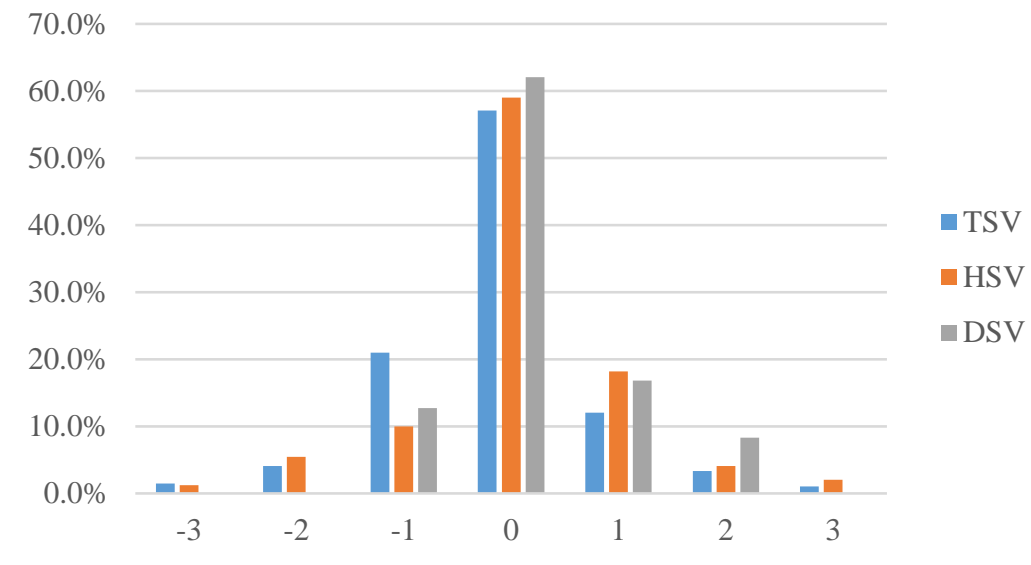

(a)

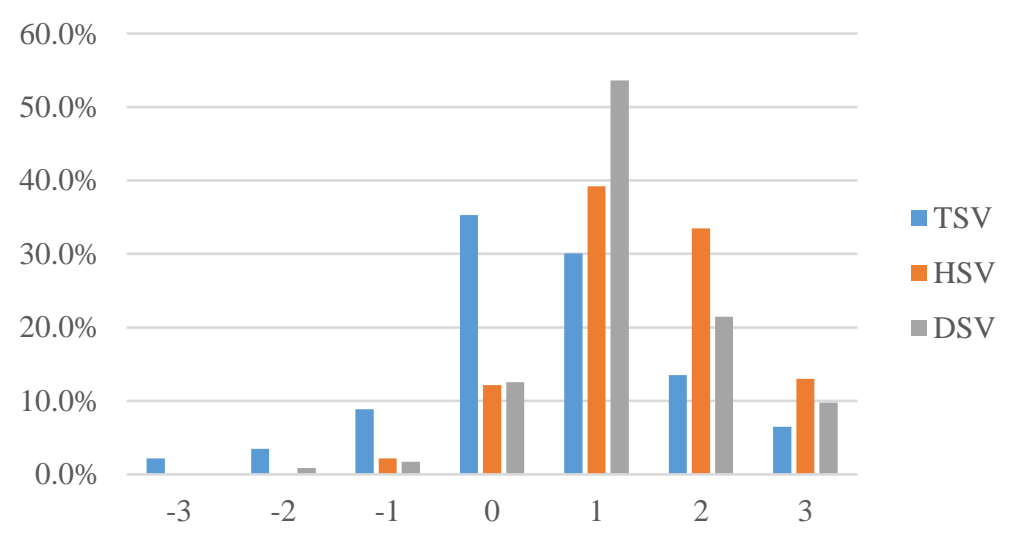

(b)

Fig. 9: TSV, HSV, DSV in summer (a) and winter (b)

\subsection{Comparative Analysis of PMV and AMV}

By using regression analysis, the correlation between the Actual Mean Vote (AMV) and indoor operative temperature in winter and summer has been obtained in addition to the correlation between the Predicted Mean Vote (PMV) and the measured indoor operating temperature in winter and summer. Fig. 10 shows the correlation of PMV and AMV with the operative temperature in summer (i.e. months June, July and August). This can be expressed in Equation 3

$$
\mathrm{AMV}=0.1923 \mathrm{~T}_{0}-4.1907 \quad\left(\mathrm{R}^{2}=0.8657\right)
$$

When $A M V=0$, then $T_{0}=21.79{ }^{\circ} \mathrm{C}$

This means that the actual indoor thermal neutral temperature of Tibetan dwellings in the summer is $21.79^{\circ} \mathrm{C}$.

$\mathrm{PMV}=0.2794 \mathrm{~T}_{\mathrm{o}}-6.6438\left(\mathrm{R}^{2}=0.9916\right)$

When $\mathrm{PMV}=0$, the predicted thermal neutral temperature of Tibetan dwellings in summer is $23.77^{\circ} \mathrm{C}$. 


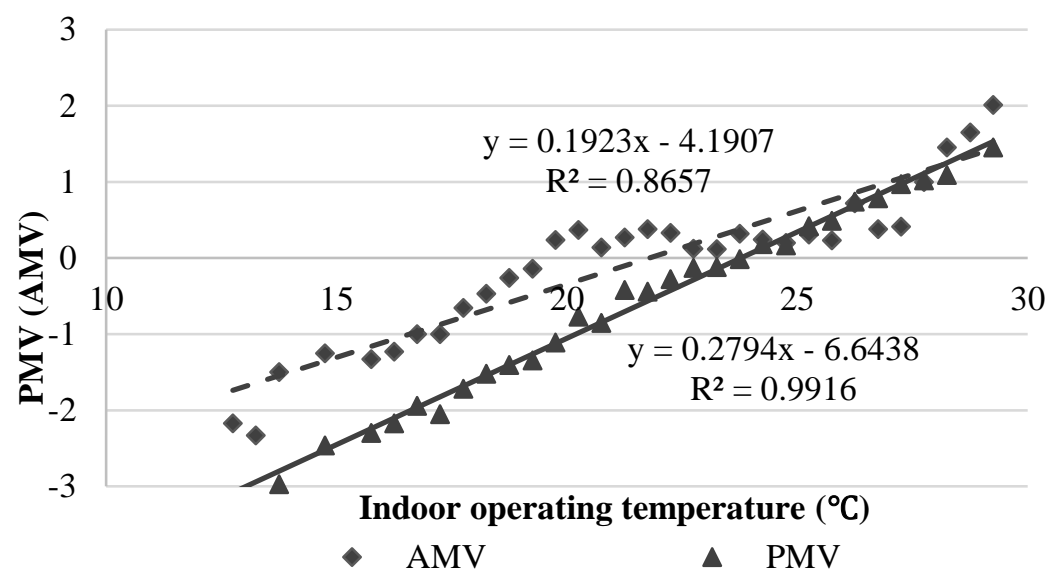

Fig. 10: The linear relationship between AMV/PMV and indoor operating temperature in summer

The actual thermal neutral temperature in this region is lower than that derived from the PMV model. In particular, within the temperature range $13^{\circ} \mathrm{C}$ to $19^{\circ} \mathrm{C}$, the $\mathrm{AMV}$ was higher than the PMV. This indicates that in summer the Tibet residents are more tolerant of the 'cold' conditions. This may be explained by the local residents having become adapted to living in the high altitude climate for many years. Besides, the low barometric pressure at high altitudes shows that the air density is low; hence the increased clothing insulation performance is possibly due to the reduced convective heat transfer coefficient between the clothing and air compared to the conditions in which the PMV model was developed. Furthermore, local residents are very active in taking adaptive measures to improve thermal comfort.

However, within the temperature range $25^{\circ} \mathrm{C}-28^{\circ} \mathrm{C}$, the AMV is slightly lower than the PMV. This indicates that the residents can also tolerate hot conditions compared to those predicted by the PMV. But when the temperature exceeds $28^{\circ} \mathrm{C}$, the residents feel hot. This is because they wear thick clothing (also called the Tibetan cloak) even in the summer, leading to higher clothing insulation. Besides, the measured parameters show that the residential indoor air velocity is low, which contributes to the occupants feeling hot.

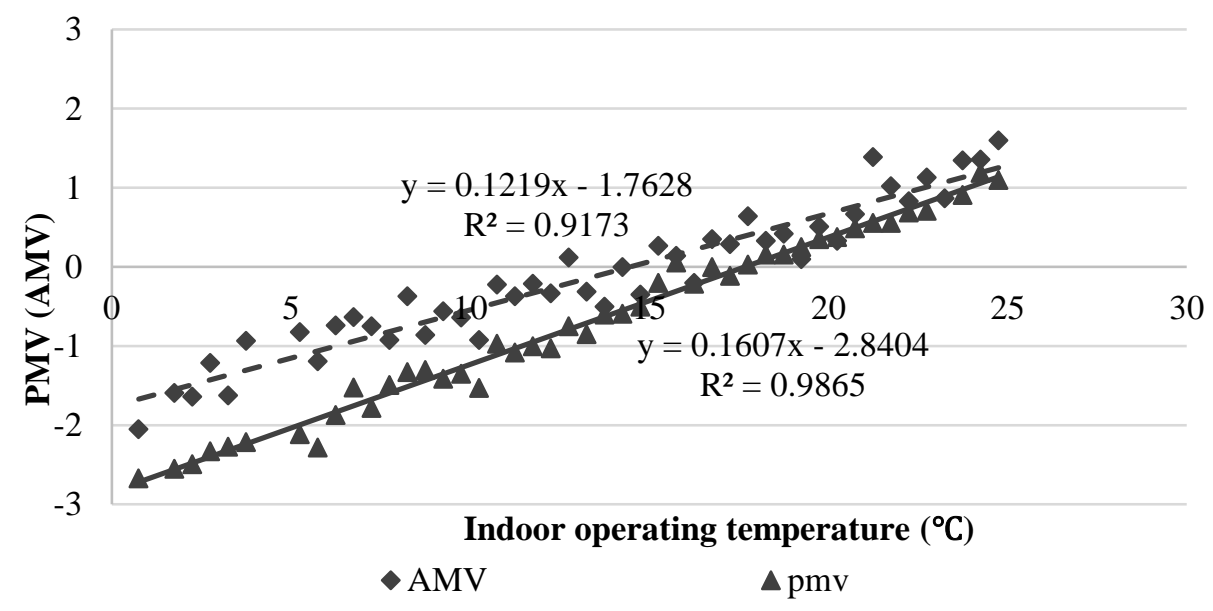

Fig. 11: Linear relations between AMV/PMV and indoor operating temperature in winter

Fig. 11 shows the correlation of PMV and AMV with the operative temperature in winter (i.e. December, January and February). This can be expressed in equation $\mathbf{5}$ 
When $\mathrm{AMV}=0$, the actual indoor thermal neutral temperature $\mathrm{T}_{\mathrm{o}}$ (actual) in winter is $14.46^{\circ} \mathrm{C}$.

$\mathrm{PMV}=0.1607 \mathrm{~T}_{\mathrm{o}}-2.8404\left(\mathrm{R}^{2}=0.9865\right)$

When PMV $=0$, then the predicted thermal neutral temperature $T_{o}$ (predicted) is $17.68^{\circ} \mathrm{C}$. The actual indoor thermal neutral temperature in this region is lower than the predicted thermal neutral temperature. Especially, within the range 0 to $10^{\circ} \mathrm{C}$, the AMV was higher than the PMV value. This can be explained as follows. In winter the residents normally wear heavy clothing and keep the windows closed. Beside the high indoor mean radiant temperature due to the high solar radiation makes the thermal sensation less cold than the predicted one. Furthermore, the residents have been living in the area for a long time and formed low expectations due to their economic circumstances. The adaptive measures for thermal comfort include putting on more layers of clothes, preventing infiltration from the doors and windows, drinking hot drinks, and using stoves in kitchens in extreme cold conditions. It is noted that the indoor operative temperatures were sometimes higher than $20^{\circ} \mathrm{C}$, even in winter, due to the strong solar radiation. In this case, the residents need to adjust their clothing or open the windows to prevent them from feeling hot.

\section{Adaptive thermal comfort}

\subsection{Obtaining the adaptive coefficient $\lambda$}

In the adaptive thermal comfort model aPMV $=\frac{\text { PMV }}{1+\lambda \times \text { PMV }}$, the coefficient $\lambda$ for Tibet's cold environment can be obtained using the least squares method ${ }^{[13]}$. Using this method, the value of the adaptive coefficient was calculated as follows:

$$
\mathrm{Q}=\sum\left(\mathrm{y}-\mathrm{y}_{\mathrm{c}}\right)^{2}=\text { minimum }
$$

Since $y_{c}=a+b x$, equation (7) becomes:

$$
\mathrm{Q}=\sum(\mathrm{y}-\mathrm{a}-\mathrm{bx})^{2}=\text { minimum }
$$

Then solving the partial derivatives for $Q$, and letting it be equal to 0 , gives:

$$
\begin{aligned}
& \frac{\partial \mathrm{Q}}{\partial \mathrm{a}}=\sum 2(\mathrm{y}-\mathrm{a}-\mathrm{bx})(-1)=0 \\
& \frac{\partial \mathrm{Q}}{\partial \mathrm{b}}=\sum 2(\mathrm{y}-\mathrm{a}-\mathrm{bx})(-\mathrm{x})=0
\end{aligned}
$$

This leads to the following:

$$
\begin{aligned}
& \sum y=n a+b \sum x \\
& \sum x y=a \sum x+b \sum x^{2}
\end{aligned}
$$

Substituting the measured data ( $x, y)$ into equation (8), the parameters $a$ and $b$ can be calculated, as follows:

$$
\begin{gathered}
\mathrm{b}=\frac{\mathrm{n} \sum \mathrm{xy}-\sum \mathrm{x} \sum \mathrm{y}}{\mathrm{n} \sum \mathrm{x}^{2}-\left(\sum \mathrm{x}\right)^{2}} \\
\mathrm{a}=\frac{\sum \mathrm{y}}{\mathrm{n}}-\mathrm{b} \frac{\sum \mathrm{x}}{\mathrm{n}}
\end{gathered}
$$

Finally, $y_{c}$ can be obtain by substituting $a$ and $b$ into the equation $\mathrm{y}_{\mathrm{c}}=\mathrm{a}+\mathrm{bx}$

In the adaptive model with $\mathrm{x}$ representing $\mathrm{x}=\frac{1}{\mathrm{PMV}}$ and $\mathrm{y}$ representing $\mathrm{x}=\frac{1}{\mathrm{aPMV}}$ 
and substituting into the adaptive model equation (2), then:

$\mathrm{y}=\mathrm{x}+\lambda,\{\mathrm{y}=\mathrm{f}(\mathrm{x})\}$

That is when $b=1$, the value of $a$ that we applied is $\lambda$.

The least squares calculation of $\mathrm{f}(x)$ gives:

$\Pi=\sum_{1}^{\mathrm{n}}\left[\mathrm{y}_{\mathrm{i}}-\mathrm{f}\left(\mathrm{x}_{\mathrm{i}}\right)\right]^{2}=\sum_{1}^{\mathrm{n}}\left[\mathrm{y}_{\mathrm{i}}-\left(\mathrm{x}_{\mathrm{i}}+\lambda\right)\right]^{2}=\min$

Let $\frac{\partial \Pi}{\partial \lambda}=0$

Then, $\frac{\partial\left[\mathrm{y}_{\mathrm{i}}-\left(\mathrm{X}_{\mathrm{i}}+\lambda\right)\right]^{2}}{\partial \lambda}=2 \sum_{1}^{\mathrm{n}}\left[\mathrm{y}_{\mathrm{i}}-\mathrm{x}_{\mathrm{i}}-\lambda\right]=0$

In the case of a cool environment i.e. when PMV $<0$, the results for 34 groups were obtained by processing the data using the bin method. Therefore,

$$
\lambda=\frac{\sum_{1}^{34}(\mathrm{y}-\mathrm{x})}{34}=-0.34
$$

Hence, the aPMV model for Tibetan dwellings can be written as follows:

$$
\text { aPMV } \left.=\frac{\text { PMV }}{1-0.34 \times \text { PMV }} \quad \text { (cold environment }\right)
$$

In order to compare the actual Predicted Mean Vote (aPMV) derived from the aPMV model and the actual thermal sensation vote (TSV), the aPMV and TSV are plotted in Fig. 12 as follows:

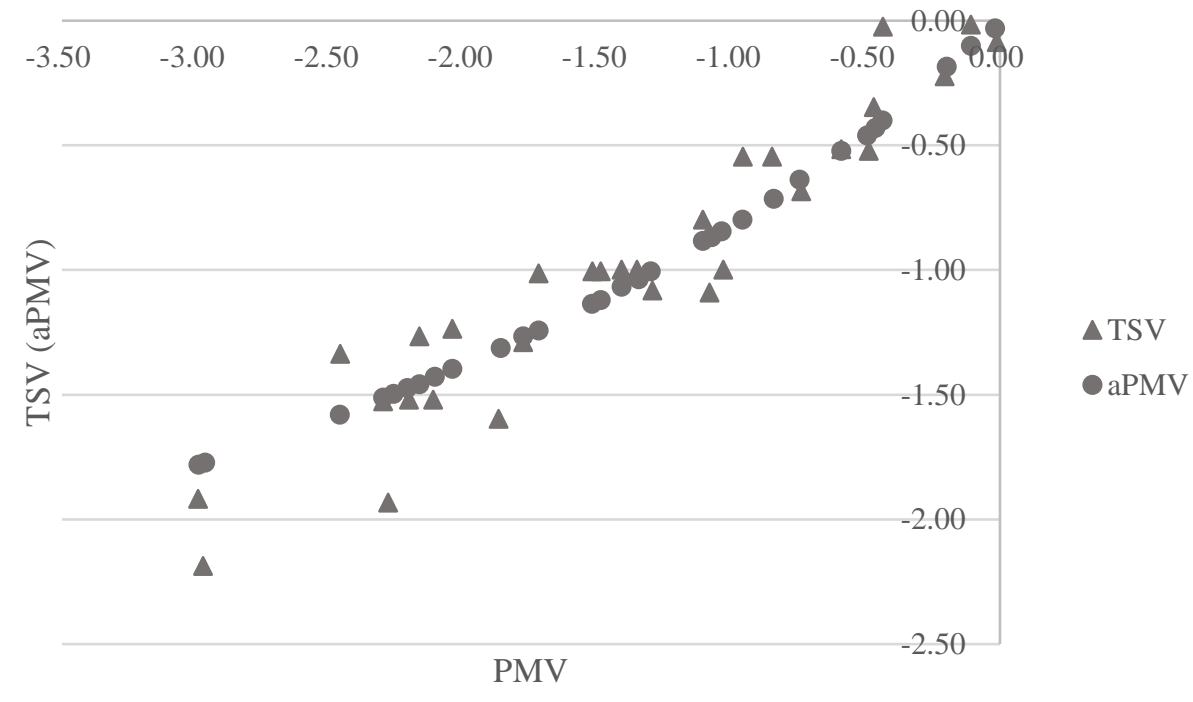

Fig. 12: Correlation between PMV, aPMV and TSV

The coloration of the two groups of data has a high degree of agreement with RMSE=0.1853.

\subsection{Acceptable thermal comfort range}

1) Acceptable indoor relative humidity range

In accordance with the Chinese regulations GB/T 50785 'Evaluation standard for indoor thermal environment in civil buildings' [50], the acceptable relative humidity range for the indoor thermal environment is $30 \%$ to $60 \%$ in winter, and $40 \%$ to $80 \%$ in summer. Most of the areas in Tibet are in the Cold and Severe Cold climatic zones of China. Based on the meteorological parameters of the major cities in China, the outdoor relative humidity range for this area is as follows: the monthly average of the coldest month in winter is $28 \%$, and the monthly average of the hottest month in summer is $54 \%$. In summary, the range of the suitable indoor relative humidity is within the $30 \%$ to $80 \%$ range in Tibet. 
2) Thermal comfort zone

The requirement for a thermal comfort temperature under non-artificial heat and within a cold environment is described in GB/T 50785 which identifies three grades of indoor thermal environment in residential buildings: Grade I in which aPMV ranges between -0.5 and 0.5 ; Grade II between -1 and -0.5 or 0.5 to 1 ; and Grade III with aPMV $<-1$ or aPMV $>1$. In Figure 15, the zone within the dashed grey line demonstrates the Grade I thermal comfort zone according to the GB/T 50785. Based on the adaptive thermal comfort model and using the adaptive thermal comfort coefficient $\lambda=-0.34$, the aPMV can be calculated under different humidity levels, using the formula $\mathrm{aPMV}=\frac{\mathrm{PMV}}{1+\lambda \times \mathrm{PMV}}$. It is worthy of note that in the calculation the velocity and clothing level are adjusted to the local residents' actual situation which is different to the one used in GB/T 50785. The indoor air velocities are 0.03 and $0.02 \mathrm{~m} / \mathrm{s}$ for the aPMV values greater and less than zero respectively, clothing levels are 1.2clo for summer and 2.2clo for winter. The people's average metabolic rate is $1.2 \mathrm{met}$ for sitting or light physical activity representing the occupants' activity in these residential buildings, which remains the same as that in GB/T 50785. Accordingly, the acceptable operating temperatures under the different humidity levels can be calculated (see Table 5).

Table 5: Acceptable operating temperature under different humidities for the Tibet area $\left({ }^{\circ} \mathrm{C}\right)$

\begin{tabular}{rccccc}
\hline & $30 \%$ & $40 \%$ & $50 \%$ & $60 \%$ & $70 \%$ \\
\hline 0.5 & 22.91 & 22.61 & 22.31 & 22.02 & 21.74 \\
\hline-0.5 & 10.18 & 9.97 & 9.75 & 9.56 & 9.36 \\
\hline
\end{tabular}

Under the following conditions: Air velocity $=0.03 \mathrm{~m} / \mathrm{s}$, clothing insulation $=1.2$ clo when aPMV $>0$, Air velocity $=0.02 \mathrm{~m} / \mathrm{s}$, clothing insulation $=2.2$ clo when $a P M V<0$; activity level $=1.2 \mathrm{met}$

Note: $\Phi$ represents the relative humidity indoors.

The thermal comfort zone for the Tibet area based on Table 5 is represented by the red dashed line in Fig. 13. From the figure, we can see that, compared to the Grade I thermal comfort zone described in the GB/T 50785, the thermal comfort zone for the Tibet area is shifted down towards the lower temperature range. The dots represent the status of the air measured in the field study. About $28.6 \%$ of the dots fall within the comfort zone for the Tibet area. 


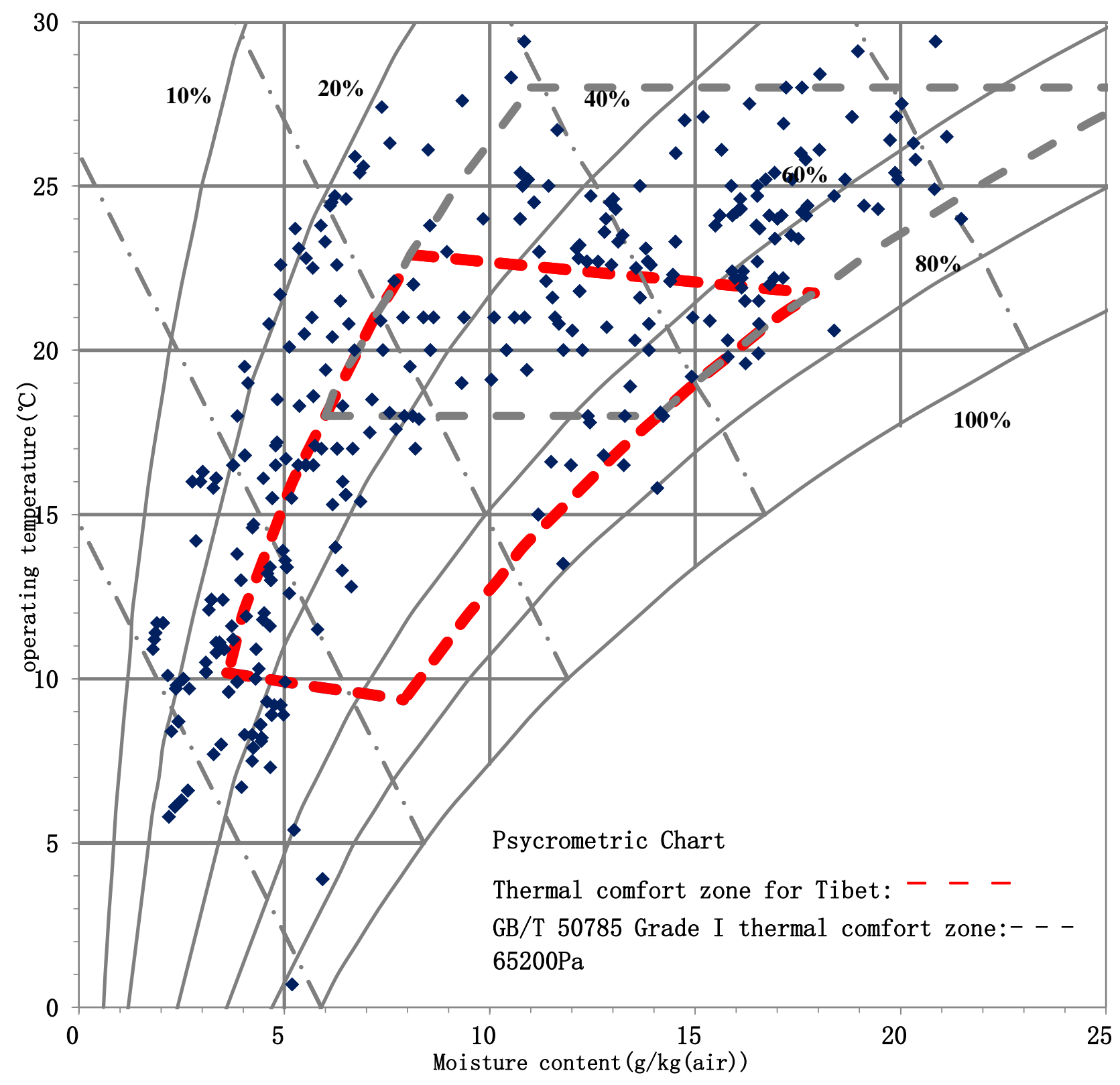

Fig.13: Thermal comfort zone for residential buildings in Lhasa

\section{Conclusions}

Tibet, located on the Qinghai-Tibetan Plateau in Southwest China, has distinct climatic characteristics and local residents who have a unique lifestyle. There is little in-depth understanding of the indoor thermal environment and local residents' living habitat. This paper presents a study of simultaneous indoor and outdoor thermal environmental measurements and a subjective questionnaire survey which was conducted in an area covering Lhasa, Shigatse, Qamdo, Nagqu, Nyingchi, Lhoka and Ngari. The research findings are summarized as follows:

1) According to the Thermal Design Code for Civil Buildings GB50176-93, the majority of areas in Tibet are classified in the 'severe cold' or 'cold' zones. However, the indoor thermal environment in Tibet is severe, particularly in winter, yet there are no central heating systems in residential buildings. Indoor air temperatures in residential buildings fluctuate greatly within the range 0 to $26^{\circ} \mathrm{C}$ during the daytime when the outdoor temperature is between -20 and $0^{\circ} \mathrm{C}$. 


\section{Thus, the indoor thermal environments are highly variable due to the great variety of heating measures that are in use.}

2) Tibetan people have a unique lifestyle in terms of thermal adaptation. They wear heavy clothing $(1.19-2.67$ clo $)$ and drink butter-sweet tea to protect themselves from cold at home in winter. The summer clothing level is between 0.43 and 1.71 clo due to the traditional dress of Tibetanstyle robes such as the Chuba. They adjust the thermal environment using shading and open windows. The indoor temperature is higher than the outdoor temperature when the outdoor temperature is between 0 to $20^{\circ} \mathrm{C}$; while the indoor temperature is mostly lower than the outdoor temperature when the outdoor temperature exceeds $20^{\circ} \mathrm{C}$. This phenomenon reflects the active behavioral adaptation.

3) By applying the adaptive thermal comfort model (aPMV model), the adaptive thermal comfort coefficient $(\lambda)$ value of -0.34 has been obtained and validated for residential buildings in Tibet. The acceptable thermal comfortable zone for the indoor environment of residential buildings in Tibet has been identified within the temperature range between $10.18^{\circ} \mathrm{C}$ and $22.91^{\circ} \mathrm{C}$ under a low relative humidity of $30 \%$ and between $9.79^{\circ} \mathrm{C}$ and $21.74^{\circ} \mathrm{C}$ under a high relative humidity of $70 \%$.

4) Compared to the thermal comfort range recommended by the "Evaluation standard for indoor thermal environment in civil buildings" (GB/T 50785-2012), the acceptance range of the Tibet acceptable comfort range is shifted towards the lower temperature. From this study we can see that Tibetan people are well adapted to the cold environment. This is mainly because they have distinctive life-styles that involve wearing heavy traditional clothing and drinking buttersweet tea. However, they are more sensitive to warm/hot environments due to their traditional dress code (0.4-1.7clo) in summer.

To summarize, the acceptable temperature range is far below that recommended in the Evaluation Standard GB/T 50785-2012. In the severe cold conditions, fires/stoves are commonly used for heating, which could cause poor indoor air quality and consequently affect people's health and wellbeing. Therefore they urgently need appropriate solutions to the heating of residential buildings in the region to meet occupant health and wellbeing demands. There is abundant solar energy which could be exploited for space heating in order to improve indoor thermal environments, for example, the passive solar house and solar energy storage systems. This research provides a comprehensive understanding of the indoor thermal environment of residential buildings in Tibet which could be referenced for the development of local thermal comfort standards and building design.

\section{Acknowledgments}

The authors would like to thank the financial support from the National Natural Science Foundation of China [grant number 51408079] and support from the 111 Project [grant number B13041]. Special thanks go to those who were involved and helped in the field survey.

\section{References:}

1. Kang, S., et al., Review of climate and cryospheric change in the Tibetan Plateau. Environmental Research Letters, 2010. 5(1): p. 015101.

2. Goldstein, M.C., A History of Modern Tibet, volume 2. 2007: University of California Press. 674.

3. Feng, Q.I., et al., Residential Indoor Thermal Environment Test and Analysis of Kangding in Winter. Building Energy Efficiency, 2015. 
4. Wang, P.Q., Y.H. Leng, and X.U. Guo-Tao, Analysis on Thermal Environment Current Situation of Residential Buildings in the South-Eastern Tibet. Building Science, 2012.

5. Suolang, B., Q. He, and J. Liu, Comparative Study on Indoor Thermal Environment in Winter of Two Tibetan Dwellings. Advances in Social Science, Education and Humanities Research, 2015.

6. Sun, H. and M. Leng, Analysis of thermal environment in Tibetan traditional dwelling building in rural area of Gannan. Journal of Civil Architectural and Environmental Engineering, 2014. 36(5): p. 29-36.

7. Sun, H. and M. Leng, Analysis on building energy performance of Tibetan traditional dwelling in cold rural area of Gannan. Energy and Buildings, 2015. 96: p. 251-260.

8. Liu, Y. and J. Liu, Measurement of thermal environment in a multistoried passive solar residence in Lhasa. Heating Ventilating and Air Conditioning, 2007.

9. Li-Ping, L.I., Research on Indoor Thermal Environment of Tibetan Traditional House with Heating or without Heating in Shangri-la. Building Science, 2009.

10. Liu, W., et al., Field Study of Thermal Comfort in a High-Altitude Region of Tibet. Journal of Convergence Information Technology, 2013.

11. Li, L.P., Analysis and Test on Indoor Thermal Environment of Tibetan-Style Dwellings of Different Materials. Advanced Materials Research, 2011. 255-260: p. 1632-1638.

12. Li, L.P., Research on Indoor Thermal Environment of Tibetan Rammed Dwellings. Advanced Materials Research, 2011. 243-249: p. 1995-1999.

13. Li, L., Indoor Thermal Environment of Tibetan Folk Houses with Rammed-earth Wall in Xiaozhongdian,Shangri-la. Huazhong Architecture, 2009.

14. Li, L., Analysis and Test of Indoor Thermal Environment of Tibetan Traditional Timber-house in Shangri-la. Huazhong Architecture, 2009.

15. Zhang, L., et al., Test study of the indoor thermal environment in winter of herdsman settlement residential building in China's western mountain grassland area. Chemical Enginering Transactions, 2015. 46: p. 703-708.

16. Wei, S., et al., New Correlations for Predicting Indoor Thermal Environment in Yunnan-Guizhou Plateau Climate. in Power and Energy Engineering Conference. 2010.

17. Chandel, S.S. and R.K. Aggarwal, Thermal Comfort Temperature Standards for Cold Regions. Innovative Energy Policies, 2012. 2(2).

18. Rijal, H.B. and H. Yoshida. Winter Thermal Comfort of Residents in the Himalaya Region of Nepal. in Summaries of Technical Papers of Meeting Architectural Institute of Japan. 2005.

19. Rijal, H.B., H. Yoshida, and N. Umemiya, Seasonal and regional differences in neutral temperatures in Nepalese traditional vernacular houses. Building and Environment, 2010. 45(12): p. 2743-2753.

20. Rijal, H.B. and H. Yoshida, Comparison of summer and winter thermal environment in traditional vernacular houses in several areas of Nepal. Advances in Building Technology, 2002: p. 1359-1366.

21. Adams, W.H. and L.J. Strang, Hemoglobin levels in persons of Tibetan ancestry living at high altitude. Experimental Biology and Medicine, 1975. 149(4): p. 1036.

22. Yan, W., et al., Applications of Appropriate Renewable Energy Technologies in Chinese Rural Houses Located in Qinghai-Tibetan Plateau. International Journal of Sustainable Building Technology and Urban Development, 2012. 2(2): p. 143-149.

23. Wang, D., et al., Design and performance of demonstration house with active solar heating in the Qinghai-Tibetan Plateau region. Annals of Tropical Medicine and Parasitology, 2015. 40(1): p. 57-61.

24. Rijal, H.B., Thermal Improvements of the Traditional Houses in Nepal for the Sustainable Building Design. Journal of the Human-Environment System, 2012. 15(1): p. 1-11.

25. Li, J. and Y. Liu, Study on Design Strategies for Improving Outdoor Thermal Comfort in the Cold Regions of China. Advanced Materials Research, 2011. 250-253: p. 3798-3801. 
26. Zhang, M., W. Yu, and B. Li, Analysis of Passive Solar House to Improve the Indoor Thermal Environment in Winter in Lhasa, China. 2015: Springer International Publishing.

27. Shen, G.F. and W.F. Bai, Research on Improving Thermal Environment of Shangri-La Tibetan Dwellings Based on the Use of Passive Solar Energy. Jiangxi Science, 2012.

28. Puri, V., et al., Bamboo reinforced prefabricated wall panels for low cost housing. Journal of Building Engineering, 2017. 9: p. 52-59.

29. GB 50176-93. China National Standard: Thermal design code for the civil building, General Administration of Quality Supervision,. 1993, Inspection and Quarantine of the People's Republic of China and the Ministry of Construction (now the Ministry of Housing and Urban-Rural Development).

30. Wang, Z., et al., Thermal comfort for naturally ventilated residential buildings in Harbin. Energy and Buildings, 2010. 42(12): p. 2406-2415.

31. Wang, Z.J., F.X. Mu, and L.L. Ming, Field experiments on occupant thermal comfort in Harbin. Journal of Harbin Institute of Technology, 2002.

32. Wang, Z., A field study of the thermal comfort in residential buildings in Harbin. Building \& Environment, 2006. 41(8): p. 1034-1039.

33. Ning, H., et al., Adaptive thermal comfort in university dormitories in the severe cold area of China. Building and Environment, 2016. 99: p. 161-169.

34. Liu, Y., et al., Residential thermal environment in cold climates at high altitudes and building energy use implications. Energy and Buildings, 2013. 62(62): p. 139-145.

35. Yan, H. and L. Yang, Indoor thermal conditions and thermal comfort in residential buildings during the winter in Lhasa, China. 2014.

36. Ning, H., et al., Thermal Comfort and Thermal Adaptation between Residential and Office Buildings in Severe Cold Area of China. Procedia Engineering, 2015. 121: p. 365-373.

37. Jin, H., H. Zhao, and X.P. Wang, Research on the indoor thermal comfort environment of rural housing in winter in super-cold region. Journal of Harbin Institute of Technology, 2006. 38(12): p. 2108-2111.

38. Qu, W.Y., Field Survey on Occupant Thermal Comfort of Cold Regions in Transition Season. Advanced Materials Research, 2013. 805-806: p. 1620-1624.

39. Fukazawa, T., Y. Tochihara, and Y. Takahara, Different Impacts of Normobaric/Hypobaric Hypoxia on Physiological and Subjective Responses at a Cold Environment. Journal of the Human-Environment System, 2013. 16(1): p. 011-019.

40. Ohno, H., et al., The effects of hypobaric conditions on man's thermal responses. Energy and Buildings, 1991. 16(1-2): p. 755-763.

41. Cui, W., et al., The influence of a low air pressure environment on human metabolic rate during shortterm $(<2 h)$ exposures. Indoor Air, 2016.

42. Wang, H., et al., Experimental study of human thermal sensation under hypobaric conditions in winter clothes. Energy and Buildings, 2010. 42(11): p. 2044-2048.

43. Wang, D., Y. Liu, and Y. Wang, Measurement and evaluation of indoor thermal environment of residential buildings in Lhasa in winter. Building Science, 2011.

44. Chang, S.K. and W.R. Santee, Clothing insulation in a hypobaric environment. Aviation Space \& Environmental Medicine, 1996. 67(9): p. 827-834.

45. Luo, Y., Improve the indoor thermal environment of Alpine Region Building Technical Measures and Research in Tibet. 2012, Southwest Jiaotong University.

46. Halawa, E. and J. van Hoof, The adaptive approach to thermal comfort: A critical overview. Energy and Buildings, 2012. 51: p. 101-110.

47. Brager, G.S. and R.J. de Dear, Thermal adaptation in the built environment: a literature review. Energy and Buildings, 1998. 27(1): p. 83-96. 
48. Nicol, J.F. and M.A. Humphreys, Adaptive thermal comfort and sustainable thermal standards for buildings. Energy and Buildings, 2002. 34(6): p. 563-572.

49. CEN EN 15251, Indoor Environmental Input Parameters for Design and Assessment of Energy Performance of Buildings Addressing Indoor Air Quality, Thermal Environment, Lighting and Acoustics, European Committee for Standardization, Brussels, Belgium, 2007.

50. Research, GB/T50785-2012, Evaluation standard for indoor thermal environments in civil buildings 2012, China Building Industry Press: Beijing.

51. ANSI/ASHRAE Standard 55, Thermal Environmental Conditions for Human Occupancy, ASHRAE Inc., Atlanta, 2013.

52. Mishra, A.K. and M. Ramgopal, Field studies on human thermal comfort - An overview. Building And Environment, 2013. 64: p. 94-106.

53. Velt, K.B. and H.A.M. Daanen, Thermal sensation and thermal comfort in changing environments. Journal of Building Engineering, 2017. 10: p. 42-46.

54. Natarajan, S., J. Rodriguez, and M. Vellei, A field study of indoor thermal comfort in the subtropical highland climate of Bogota, Colombia. Journal of Building Engineering, 2015. 4: p. 237-246.

55. Yao, R., B. Li, and J. Liu, A theoretical adaptive model of thermal comfort - Adaptive Predicted Mean Vote (aPMV). Building and Environment, 2009. 44(10): p. 2089-2096.

56. Singh, M.K., S. Mahapatra, and S.K. Atreya, Adaptive thermal comfort model for different climatic zones of North-East India. Applied Energy, 2011. 88(7): p. 2420-2428.

57. Liu, H., et al., Seasonal variation of thermal sensations in residential buildings in the Hot Summer and Cold Winter zone of China. Energy and Buildings, 2017. 140: p. 9-18.

58 Meteorological information center of China Meteorological Information Center, ed. Special meteorological data set for building thermal environment analysis in China. 2005, China Architecture and Building Press.

59. Wang, X., Huang, C. and Ye, J., Discussion about Field Measurement Technology and Methods on PMV in an Ecological Building. Building Energy and Environment, 2007. 2(26): p. 83-87.

60. Fanger, P.O. ed. Thermal comfort. 1970, Danish Technical Press: Copenhagen, Denmark.

61. Zhu, Y., Yang, J., and Zhao, X., An introduction to probability and statistical method. Northwest Polytechnical University Press, 1986.

62. ISO 7730:2005, Ergonomics of the thermal environment - Analytical determination and interpretation of thermal comfort using calculation of the PMV and PPD indices and local thermal comfort criteria, International Standardization Organization, Geneva, 2005. 


\section{Questionnaire of Indoor Thermal Environments for Summer Survey}

The field survey is supported by the National Science \& Technology Support Project of China, aiming to lay the foundation for governments to make national policies of energy-saving and emission-reduction as well as human well-being improvement. Please fill in the questionnaires during the survey with much patience, and all the information would be kept absolutely secret except for research only. We appreciate it very much for your participation and support for our projects.

\section{The First Part (for respondents)}

Sex: Male $\square$ Female $\square, \quad$ Age:

, Height: , Weight: , Occupation:

Length of residence: year (s)

\begin{tabular}{|c|c|c|}
\hline \multicolumn{2}{|c|}{ 1. Built time for present building: } & Before 70s $\square, 70 \mathrm{~s} \square, \quad 80 \mathrm{~s} \square, \quad 90 \mathrm{~s} \square$, new buildings $\square$ \\
\hline \multicolumn{2}{|c|}{ 2. Present dressing: } & $\begin{array}{l}\text { upper: shirt } \square, \text { T-shirt } \square, \text { a suit and tie } \square \text {, thin coat } \square \text {, none } \square \\
\text { lower: trousers } \square, \text { shorts } \square \text {, dresses } \square \text {, skirts } \square \text {, } \\
\text { shoes: sneaker } \square, \text { leather shoes } \square \text {, sandals } \square \text {, slipper } \square, \\
\text { socks: socks(thin) } \square, \text { silk socks } \square \text {, none }, \\
\text { others: }\end{array}$ \\
\hline \multicolumn{2}{|c|}{ 3. Time spending in this room: } & $\begin{array}{l}\text { morning } \square, \text { noon } \square, \text { afternoon } \square, \quad \text { evening } \square, \quad \text { all day } \square \\
\text { total hours: }\end{array}$ \\
\hline $\begin{array}{l}\text { 4. Feeling at } \\
\text { present: }\end{array}$ & \multicolumn{2}{|c|}{$\begin{array}{l}\text { temperature: } \quad \text { hot } \square, \text { warm } \square, \text { slightly warm } \square, \text { neutral } \square, \text { slightly cool } \square, \text { cool } \square, \text { cold } \square \\
\text { humidity : very humid } \square \text {, humid } \square \text {, slightly humid } \square, \quad \text { neutral } \square, \text { slightly dry } \square, \text { dry } \square \text {, too dry } \square \\
\text { air movement: too stuffy } \square, \text { stuffy } \square \text {, slightly stuffy } \square, \quad \text { neutral } \square \text {, slightly breezy } \square \text {, breezy }, \\
\text { very breezy } \square\end{array}$} \\
\hline \multicolumn{2}{|c|}{ 5. Thermal satisfaction presently: } & $\begin{array}{l}\text { dissatisfied } \square, \text { slightly dissatisfied } \square, \text { acceptable } \square \text {, slightly satisfied } \square \text {, } \\
\text { satisfied } \square\end{array}$ \\
\hline \multicolumn{2}{|c|}{ 6. If dissatisfied, the reason is: } & $\begin{array}{l}\text { none } \square \text {, cold } \square \text {, hot } \square \text {, humid } \square \text {, dry } \square \text {, stuffy } \square \text {, draugh } \\
\text { others: }\end{array}$ \\
\hline \multicolumn{2}{|c|}{$\begin{array}{l}\text { 7. Thermal expectation for indoor } \\
\text { thermal environments: }\end{array}$} & $\begin{array}{lccc}\text { temperature: } & \text { upper } \square, \quad \text { no change } \square, & \text { lower } \square \\
\text { humidity: } & \text { upper } \square, & \text { no change } \square, & \text { lower } \square \\
\text { air velocity: } & \text { upper } \square, & \text { no change } \square, & \text { lower } \square \\
\end{array}$ \\
\hline \multicolumn{2}{|c|}{$\begin{array}{l}\text { 8. Which ways would like to } \\
\text { improve individual thermal } \\
\text { comfort: }\end{array}$} & $\begin{array}{l}\text { comfortable, no change } \square \text {, using air-conditioning } \square \text {, opening window for } \\
\text { ventilation } \square \text {, closing window } \square \text {, add clothing, take off clothing, hot } \\
\text { drinks, cool drinks, light activities, changing postures } \square \text {, others: } \\
\end{array}$ \\
\hline \multicolumn{2}{|c|}{$\begin{array}{l}\text { 9. The habit, time and reason for } \\
\text { window opening: }\end{array}$} & $\begin{array}{l}\text { habits: } \quad \text { frequently } \square, \quad \text { occasionally } \square, \quad \text { seldom } \square \text {; } \\
\text { time: } \quad \text { morning } \square, \quad \text { noon } \square, \quad \text { afternoon } \square, \quad \text { evening } \square \text {; } \\
\text { reasons: smoking } \square, \quad \text { stuffy } \square, \quad \text { ventilation } \square, \quad \text { lighting } \square\end{array}$ \\
\hline
\end{tabular}




\begin{tabular}{|c|c|}
\hline $\begin{array}{l}\text { 10. Do you use air-conditioning } \\
\text { frequently in summer: }\end{array}$ & $\begin{array}{l}\mathrm{YES} \square, \mathrm{NO} \square \text {; if it is no, please choose the reason: } \\
\text { (1) comfortable, no need } \square \text {, (2) unlike, draught } \square \text {, (3)poor air circulation } \square \text {, } \\
\text { (4)power saving } \square \text {, (5) using other regulation methods } \square \text {, (6)without devices } \\
\text { in rooms } \square\end{array}$ \\
\hline $\begin{array}{l}\text { 11. What are you feelings } \\
\text { for a long time? }\end{array}$ & $\begin{array}{l}\text { Fatigue and drowsiness } \square \text {, nausea and dizzy } \square \text {, hot and upset } \square \text {, eyes } \\
\text { irritation } \square \text {, sore throat } \square \text {, nose discomfort and shortness of breath } \square \text {, } \\
\text { tinnitus } \square \text {, impaired concentration } \square \text {, dry, itchy and rash of skin } \square \text {, none } \square\end{array}$ \\
\hline $\begin{array}{lrr}\text { 12. The overall } & \text { thermal } \\
\text { acceptability for } & \text { thermal } \\
\text { environments: } & & \\
\end{array}$ & $\begin{array}{l}\text { absolutely unacceptable } \square, \text { unacceptab } \\
\text { slightly acceptable } \square, \text { acceptable } \square, \text { ab }\end{array}$ \\
\hline
\end{tabular}


City: Building name:

Types of community : residences $\square$, downtown $\square ; \quad$ others $\square$

Dates: mm dd Time:

Weather（sunny $\square$ cloudy $\square$ rain $\square$ snow $\square$ )

Tester name:

\begin{tabular}{|c|c|}
\hline 1. Building structure: & Masonry-concrete structure $\square$, Reinforced Concrete Structure $\square, \quad$ others $\square$ \\
\hline 2. Building location: & Along the street $\square, \quad$ away from street $\square$; suburb $\square$ \\
\hline 3. Total layers and floor: & (basement excluded) \\
\hline $\begin{array}{l}\text { 4. Window orientation for } \\
\text { measuring room: }\end{array}$ & $\begin{array}{l}\text { east } \square \text {, south } \square \text {, west } \square \text {, north } \square \text {, southeast } \square \text {, northeast } \square \text {, southwest } \square \text {, } \\
\text { northwest } \square\end{array}$ \\
\hline 5. Type of rooms: & Living rooms: \\
\hline 6. Room areas: & areas:___ $\mathrm{m}^{2}$, window (overall: __ $\mathrm{m}^{2}$, opening areas__ $\mathrm{m}^{2}$ ) \\
\hline 7. Types of windows: & $\begin{array}{l}\text { Single frame with single glass } \square \text {, single frame with double glass } \square \text {, double } \\
\text { frames with double glass } \square\end{array}$ \\
\hline $\begin{array}{l}\text { 8. The number of people } \\
\text { presently in room: }\end{array}$ & Number: \\
\hline 9. Activities for respondents: & reclining $\square$, sitting $\square$, standing $\square$, walking $\square$ \\
\hline $\begin{array}{l}\text { 10. The window condition at } \\
\text { present: }\end{array}$ & close $\square$ \\
\hline $\begin{array}{l}\text { 11. The regulation method } \\
\text { for indoor thermal } \\
\text { environments at present: }\end{array}$ & $\begin{array}{l}\text { Air-conditioning } \square, \text { household central air-conditioning } \square \text {, central cooling } \square \text {, } \\
\text { air conditioning fan } \square \text {, electric fan } \square \text {, naturally ventilation, without } \\
\text { regulation measures } \square, \text { others: }\end{array}$ \\
\hline $\begin{array}{l}\text { 12. Is the air-conditioning } \\
\text { opened? if so, the set-point is : }\end{array}$ & $\begin{array}{l}\text { Yes } \square, \text { No } \square \\
\text { Under 20oC } \square, 20 \circ C \square, \quad 21 \circ \mathrm{oC} \square, 22 \circ \mathrm{oC}, 23 \circ \mathrm{oC} \square, 24 \circ \mathrm{oC}, 25 \circ \mathrm{oC} \square, 26 \circ \mathrm{\circ} \square \text {, } \\
27 \circ \mathrm{oC} \square, \quad \geq 28 \circ \mathrm{oC} \square, \quad \text { unclear } \square\end{array}$ \\
\hline
\end{tabular}




\section{The Third Part (environmental parameters)}

1. Test instrument type: Temperature and humidity meter:

Anemometer:

2. Instrument accuracy: Temperature and humidity meter: Anemometer:

3. Recording table :

\begin{tabular}{|l|l|l|l|}
\hline $\begin{array}{l}\text { Outdoor air } \\
\text { temperature oC: }\end{array}$ & $\begin{array}{l}\text { Indoor air } \\
\text { temperature oC: }\end{array}$ & \\
\hline $\begin{array}{l}\text { Outdoor relative } \\
\text { humidity \%: }\end{array}$ & $\begin{array}{l}\text { Indoor relative } \\
\text { humidity \%: }\end{array}$ & \\
\hline $\begin{array}{l}\text { Outdoor air } \\
\text { velocity m/s: }\end{array}$ & $\begin{array}{l}\text { Indoor air } \\
\text { velocity } \mathrm{m} / \mathrm{s}:\end{array}$ & \\
\hline
\end{tabular}




\section{Questionnaire of Indoor Thermal Environments for Winter Survey}

The field survey is supported by the National Science \& Technology Support Project of China, aiming to lay the foundation for governments to make national policies of energy-saving and emission-reduction as well as human well-being improvement. Please fill in the questionnaires during the survey with much patience, and all the information would be kept absolutely secret except for research only. We appreciate it very much for your participation and support for our projects.

\section{The First Part (for respondents)}

Sex: Male $\square$ Female $\square, \quad$ Age: , Height: , Weight: , Occupation:

Length of residence: year (s)

\begin{tabular}{|c|c|}
\hline $\begin{array}{l}\text { 13. Built time for present } \\
\text { building: }\end{array}$ & Before 70s $\square, 70 \mathrm{~s} \square, \quad 80 \mathrm{~s} \square, \quad 90 \mathrm{~s} \square$, new buildings $\square$ \\
\hline 14. Present dressing: & 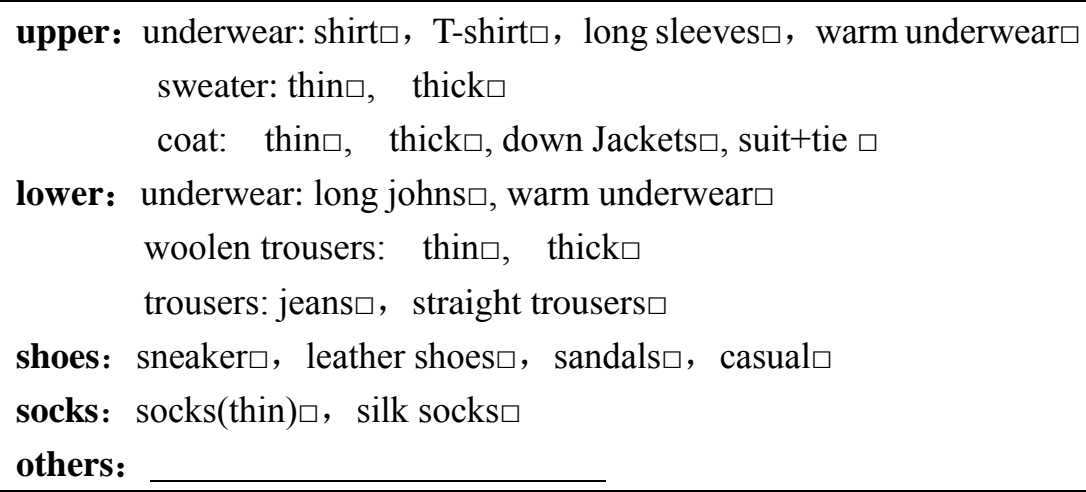 \\
\hline 15. Time spending in this room: & $\begin{array}{l}\text { morning } \square, \text { noon } \square, \text { afternoon } \square, \quad \text { evening } \square, \quad \text { all day } \square \\
\text { total hours: }\end{array}$ \\
\hline \multicolumn{2}{|c|}{ 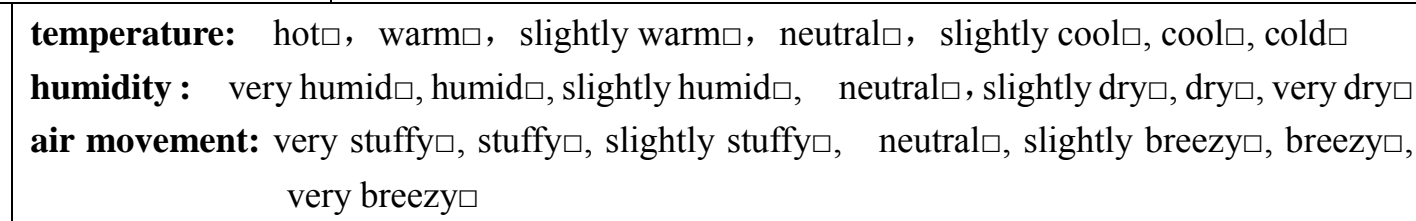 } \\
\hline $\begin{array}{l}\text { 17. Thermal } \\
\text { presently: }\end{array}$ & $\begin{array}{l}\text { dissatisfied } \square \text {, slightly dissatisfied } \square \text {, acceptable } \square \text {, slightly satisfied } \square \text {, } \\
\text { satisfied } \square\end{array}$ \\
\hline 18. If dissatisfied, the reason is: & $\begin{array}{l}\text { none } \square \text {, cold } \square \text {, hot } \square \text {, humid } \square \text {, dry } \square \text {, stuffy } \square \text {, draught } \square \text {, } \\
\text { others: }\end{array}$ \\
\hline $\begin{array}{l}\text { 19. Thermal expectation for } \\
\text { indoor thermal environments: }\end{array}$ & $\begin{array}{lccc}\text { temperature: } & \text { upper } \square, & \text { no change } \square, & \text { lower } \square \\
\text { humidity: } & \text { upper } \square, & \text { no change } \square, & \text { lower } \square \\
\text { air velocity: } & \text { upper } \square, & \text { no change } \square, & \text { lower } \square\end{array}$ \\
\hline $\begin{array}{l}\text { 20. Which ways would like to } \\
\text { improve individual thermal }\end{array}$ & $\begin{array}{l}\text { comfortable, no change } \square \text {, using air-conditioning or heater } \square \text {, opening } \\
\text { window for ventilation } \square \text {, closing window } \square \text {, add clothing } \square \text {, take off }\end{array}$ \\
\hline
\end{tabular}




\begin{tabular}{|c|c|}
\hline com & clothing $\square$, hot drinks $\square$, light activities $\square$, changing postures $\square$, others: \\
\hline $\begin{array}{l}\text { 21. The habit, time and reason } \\
\text { for window opening: }\end{array}$ & $\begin{array}{l}\text { habits: } \quad \text { frequently } \square, \quad \text { occasionally } \square, \quad \text { seldom } \square ; \\
\text { time: } \quad \text { morning } \square, \quad \text { noon } \square, \quad \text { afternoon } \square, \quad \text { evening } \square \text {; } \\
\text { reasons: } \quad \text { smoking } \square, \quad \text { stuffy } \square, \quad \text { ventilation } \square, \quad \text { lighting } \square\end{array}$ \\
\hline $\begin{array}{l}\text { 22. Do you use air-conditioning } \\
\text { and other devices frequently for } \\
\text { heating: }\end{array}$ & $\begin{array}{l}\text { YES } \square, \mathrm{NO} \square \text {; if it is no, please choose the reason: } \\
\text { (1)comfortable, no need } \square \text {, (2) unlike, draught } \square \text {, (3)poor air circulation } \square \text {, } \\
\text { (4)power saving } \square \text {, (5) using other regulation methods } \square \text {, (6)without devices } \\
\text { in rooms } \square\end{array}$ \\
\hline $\begin{array}{l}\text { 23. How are you feelings in the } \\
\text { room for a long time? }\end{array}$ & $\begin{array}{l}\text { Fatigue and drowsiness } \square \text {, nausea and dizzy } \square \text {, hot and upset } \square \text {, eyes } \\
\text { irritation } \square \text {, sore throat } \square \text {, nose discomfort and shortness of breath } \square \text {, } \\
\text { tinnitus } \square \text {, impaired concentration } \square \text {, dry, itchy and rash of skin } \square \text {, none } \square\end{array}$ \\
\hline $\begin{array}{lrr}\text { 24. The overall } & \text { thermal } \\
\text { acceptability for } & \text { thermal } \\
\text { environments: } & & \\
\end{array}$ & $\begin{array}{l}\text { absolutely unacceptable } \square, \text { unacceptably } \square \text {, slightly unacceptable } \square \text {, } \\
\text { slightly acceptable } \square \text {, acceptable } \square, \text { absolutely acceptable } \square\end{array}$ \\
\hline
\end{tabular}


The Second Part (for testers)

City: Building name:

Types of community : residences $\square$ downtown $\square$ others $\square$

Dates: yy__ mm__ dd Time:

Weather（sunny $\square$ cloudy $\square$ rain $\square$ snow $\square$ ）

Tester name:

\begin{tabular}{|c|c|}
\hline 12. Building structure: & Masonry-concrete structure $\square$, Reinforced Concrete Structure $\square, \quad$ others $\square$ \\
\hline 13. Building location: & Along the street $\square, \quad$ away from street $\square$; suburb $\square$ \\
\hline 14. Total layers and floor: & (basement excluded) \\
\hline $\begin{array}{l}\text { 15. Window orientation for } \\
\text { measuring room: }\end{array}$ & $\begin{array}{l}\text { east } \square \text {, south } \square \text {, west } \square \text {, north } \square \text {, southeast } \square \text {, northeast } \square \text {, southwest } \square \text {, } \\
\text { northwest } \square\end{array}$ \\
\hline 16. Type of rooms: & Living rooms: \\
\hline 17. Room areas: & areas:___ $\mathrm{m}^{2}$, window (overall: $\ldots \mathrm{m}^{2}$, opening areas__ $\mathrm{m}^{2}$ ) \\
\hline 18. Types of windows: & $\begin{array}{l}\text { Single frame with single glass } \square \text {, single frame with double glass } \square \text {, double } \\
\text { frames with double glass } \square\end{array}$ \\
\hline $\begin{array}{l}\text { 19. The number of people } \\
\text { presently in room: }\end{array}$ & Number: \\
\hline 20. $\frac{\text { Activities for }}{\text { respondents: }}$ & reclining $\square$, sitting $\square$, standing $\square$, walking $\square$ \\
\hline $\begin{array}{l}\text { 21. The window condition at } \\
\text { present: }\end{array}$ & open $\square$, \\
\hline $\begin{array}{l}\text { 22. The regulation method } \\
\text { for indoor thermal } \\
\text { environments at present: }\end{array}$ & $\begin{array}{l}\text { heater fan } \square \text {, electric furnace } \square \text {, air-conditioning } \square \text {, household central air- } \\
\text { conditioning } \square \text {, central heating } \square \text {, electric heater } \square \text {, naturally ventilation } \square \text {, } \\
\text { without regulation measures } \square \text {, others: }\end{array}$ \\
\hline $\begin{array}{l}\text { 12. Is the air-conditioning } \\
\text { opened? if so, the set-point is : }\end{array}$ & $\begin{array}{l}\text { Yes } \square, \text { No } \square \\
\text { Under 20oC } \square, 20 \circ C \square, \quad 21 \circ C \square, 22 \circ \mathrm{O} \square, 23 \circ C \square, 24 \circ C \square, 25 \circ C \square, 26 \circ C \square, \\
27 \circ C \square, \quad \geq 28 \circ C \square, \quad \text { unclear } \square\end{array}$ \\
\hline
\end{tabular}




\section{The Third Part (environmental parameters)}

1. Test instrument type: Temperature and humidity meter:

2. Instrument accuracy: Temperature and humidity meter:

3. Recording table :

\begin{tabular}{|l|l|l|l|}
\hline $\begin{array}{l}\text { Outdoor air } \\
\text { temperature oC: }\end{array}$ & $\begin{array}{l}\text { Indoor air } \\
\text { temperature oC: }\end{array}$ \\
\hline $\begin{array}{l}\text { Outdoor relative } \\
\text { humidity \%: }\end{array}$ & $\begin{array}{l}\text { Indoor relative } \\
\text { humidity \%: }\end{array}$ \\
\hline $\begin{array}{l}\text { Outdoor air } \\
\text { velocity }\end{array}$ & $\begin{array}{l}\text { Indoor air } \\
\text { velocity }\end{array}$ & \\
$\mathrm{m} / \mathrm{s}:$ & $\mathrm{m} / \mathrm{s}:$ & \\
\hline
\end{tabular}

Anemometer:

Anemometer: 
